\title{
SiC-Based Composites Sintered with High Pressure Method
}

\author{
Piotr Klimczyk \\ Institute of Advanced Manuacturing Technology \\ Poland
}

\section{Introduction}

Silicon carbide-based materials usually have high hardness $(2500-2800 \mathrm{HV})$ and thus have superior wear resistance. Nevertheless, the tribological performance of $\mathrm{SiC}$ is determined by many factors, such as the grain size of mated materials or the reactions in the presence of oxygen and humidity in the surrounding atmosphere. For example, in unlubricated sliding, wear resistance of $\mathrm{SiC}$ ceramics can be greater in air than in inert atmosphere owing to thin soft oxide films reducing friction and local surface pressure. (Gahr et al., 2001; Guicciardi et al., 2007). The friction and wear properties of $\mathrm{SiC}$ materials (both in dry and lubricating conditions) have been studied extensively because they are used in applications like bearings, cylinder liners and mechanical seals (Murthy et al., 2004).

Silicon carbide-based ceramics have high melting point $\left(\sim 2500^{\circ} \mathrm{C}\right)$, high thermal conductivity ( $43-145 \mathrm{~W} / \mathrm{m} \cdot \mathrm{K}$ - depending on a temperature and phase composition), low thermal expansion $\left(\sim 4,5 \times 10^{-6} \cdot \mathrm{K}^{-1}\right)$, and high temperature capability. Silicon carbide is a semiconductor which can be doped n-type by nitrogen or phosphorus and p-type by aluminium, boron, gallium or beryllium. Due to the combination of its thermal and electrical properties, $\mathrm{SiC}$ is applied in a resistance heating, flame igniters and electronic components. Relatively pure $\mathrm{SiC}$ has also an excellent corrosion resistance in the presence of hot acids and bases (Richerson, 2004).

Silicon carbide powder compacts are difficult to densify without additives because of the covalent nature of the Si-C bonds and the associated low self-diffusion coefficient. Therefore, Reaction Sintering (RS) in the presence of liquid silicon as well as Hot Isotactic Pressing (HIP) are frequently used to obtain a high quality, full dense SiC ceramics. Typical room temperature flexural strength of SiC-based materials is about 350-550 MPa. High-strength RS-SiC (over $1000 \mathrm{MPa}$ in a 3-point bending test) was developed by controlling the residual Si size under $100 \mathrm{~nm}$. (Magnani et al., 2000; Suyama et al., 2003). Silicon carbide ceramics have the ability to increase in strength with increase of temperature. It was reported that flexural strength of some kind of commercial $\mathrm{SiC}$ ceramic increase is from $413 \mathrm{MPa}$ at the room temperature to around $580 \mathrm{MPa}$ at $1800{ }^{\circ} \mathrm{C}$ (Richerson, 2004). For hot-pressed silicon carbide with addition of 0.15-1.0 wt $\% \mathrm{Al}_{2} \mathrm{O}_{3}$, the high-temperature strength has been improved from $200 \mathrm{MPa}$ to $700 \mathrm{MPa}$ by decreasing the grain boundary concentration of both $\mathrm{Al}$ and $\mathrm{O}$ at $1500{ }^{\circ} \mathrm{C}$ (Kinoshita et al., 1997). 
A favorable combination of properties makes $\mathrm{SiC}$ materials suitable for many engineering applications, including parts of machines and devices exposed to the abrasion, the high temperature, the corrosive environment, etc. A major disadvantage of $\mathrm{SiC}$ ceramic materials is their low fracture toughness, which usually does not exceed about $3.5 \mathrm{MPa} \cdot \mathrm{m}^{1 / 2}$ (Lee et al., 2007; Suyama et al., 2003). Low values of $\mathrm{K}_{\text {Ic }}$ coefficient exclude these materials from numerous applications with dynamic loads, e.g. in machining processes.

There are various ways to improve the fracture toughness of ceramic materials. One of them involves obtaining a composite material by the introduction of the additional phases in the form of nano-, micro- or sub-micro-sized particles to the base material. Some papers indicate that nanosized structures have great potential to essentially improve the mechanical performance of ceramic materials even at high temperatures (Awaji et al., 2002; Derby, 1998; Kim et al., 2006; Niihara et al., 1999). Depending on the type of introduced particles, composites can take advantage of different strengthening mechanisms, such as the crack deflection, crack bridging, crack branching, crack bowing, crack pinning, microcracking, thermal residual stress toughening, transformation toughening and synergism toughening. For example, metallic particles are capable of plastic deformation, thus absorption of energy and bridging of a growing crack, resulting in increased strengthening (Fig. 1a) (Yeomans, 2008). On the other hand, hard ceramic particles, like borides or nitrides, can introduce a favorable stress state which can cause a toughening effect by crack deflection and crack bifurcation (Fig. 1b) (Xu, 2005). An addition of metal borides such as $\mathrm{ZrB}_{2}, \mathrm{TaB}_{2}, \mathrm{NbB}_{2}$ or $\mathrm{TiB}_{2}$, promote densification of $\mathrm{SiC}$ powder as well as improve hardness and other mechanical properties of the material as a whole (Tanaka et al., 2003).

a)

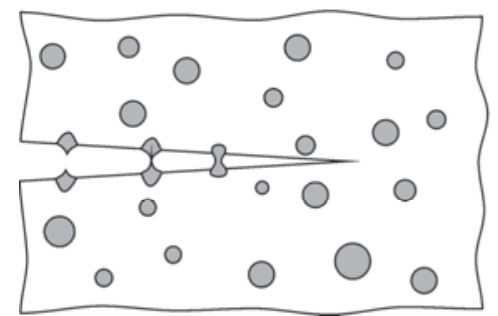

b)

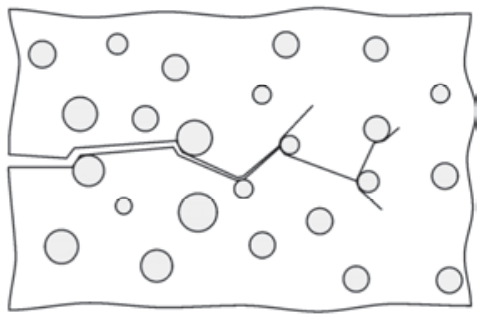

Fig. 1. Example of strengthening mechanisms which can occur in ceramic matrix composites with dispersed "soft" metallic or/and "hard" ceramic particles: a) crack bridging, b) crack deflection and crack bifurcation

The wide group of materials containing the silicon carbide are $\mathrm{SiC} / \mathrm{Si}_{3} \mathrm{~N}_{4}$ composites. In such materials predominant phase is silicon nitride, while SiC content does not usually exceed $30 \mathrm{vol} . \%$. Silicon nitride has a lower hardness but a higher fracture toughness than silicon carbide. If $\mathrm{SiC}$ particles are uniformly dispersed in the $\mathrm{Si}_{3} \mathrm{~N}_{4}$ ceramics, high strength can be obtained from room temperature to elevated temperature. It was reported that the strength of $1000 \mathrm{MPa}$ at $1400^{\circ} \mathrm{C}$ is obtained in nano-composites having ultra-fine $\mathrm{SiC}$ particles added into the $\mathrm{Si}_{3} \mathrm{~N}_{4}$ matrix. This improvement was mainly attributed to the suppression of a grain boundary sliding by intergranular $\mathrm{SiC}$ particles bonded directly with the $\mathrm{Si}_{3} \mathrm{~N}_{4}$ grain in the atomic scale without any impurity phases (Hirano \& Niihara, 1995; Yamada \& Kamiya, 1999). $\mathrm{SiC} / \mathrm{Si}_{3} \mathrm{~N}_{4}$ composites have an ability to crack healing under high temperature and applied stress, to exhibit a significantly higher creep resistance and fracture 
toughness compared to the monolithic materials. (Ando et al., 2002; Lojanová et al., 2010; Sajgalík et al., 2000; Takahashi et al., 2010).

The combination of the fair fracture toughness with high hardness, wear resistance and mechanical strength at elevated temperatures makes $\mathrm{SiC} / \mathrm{Si}_{3} \mathrm{~N}_{4}$ ceramics a promising material for cutting tools (Eblagon et al., 2007). Despite many studies on materials based on silicon carbide and silicon nitride, there is a lack of knowledge about the $\mathrm{SiC} / \mathrm{Si}_{3} \mathrm{~N}_{4}$ composites where the predominant phase is $\mathrm{SiC}$. In the presented work, the materials contained from 0 to $100 \%$ of silicon carbide were investigated.

\section{Description of experiment}

The purpose of the presented experiment was to study the influence of High Pressure - High Temperature (HPHT) sintering on the phase composition, microstructure and selected properties of $\mathrm{SiC} / \mathrm{Si}_{3} \mathrm{~N}_{4}$ composites as well as to study the effect of the addition of thirdphase particles selected from metals (Ti) or ceramics $\left(\mathrm{TiB}_{2}, \mathrm{cBN}\right.$ - cubic Boron Nitride) to the $\mathrm{SiC}-\mathrm{Si}_{3} \mathrm{~N}_{4}$ system. The main goal was to improve fracture toughness and wear resistance of the investigated materials.

The composites were manufactured and tested in two stages. The first stage consisted in sintering of materials having, in its initial composition, only $\mathrm{SiC}$ and/or $\mathrm{Si}_{3} \mathrm{~N}_{4}$ powder(s). Samples sintered from nano-, sub-micro- and micropowders with various silicon carbide to silicon nitride ratios were investigated at this stage.

At the second stage the best $\mathrm{SiC} / \mathrm{Si}_{3} \mathrm{~N}_{4}$ composite manufactured at the first stage was subjected to modification, consisting of:

- use of various types of $\mathrm{SiC}$ and $\mathrm{Si}_{3} \mathrm{~N}_{4}$ powders,

- $\quad$ addition of metallic phase in the form of Ti particles,

- addition of boride $\left(\mathrm{TiB}_{2}\right)$ phase,

- $\quad$ addition of superhard (cBN) phase.

All materials were sintered with the HPHT method. The parameters of sintering: time and temperature were chosen individually for each composition. The obtained samples were subjected to a series of studies, which included: phase composition and crystallite size analysis by X-ray diffraction, measurements of density by hydrostatic method and Young's modulus by the ultrasonic method, measurement of hardness and and fracture toughness using Vickers indentation as well as studies of tribological properties using the Ball-On-Disk method.

\subsection{HPHT method of sintering}

Pressure is a versatile tool in solid state physics, materials engineering and geological sciences. Under the influence of high pressure and temperature there are a lot of changes in physical, chemical and structural properties of materials (Eremets, 1996). It gives a possibility to generate of new, non-existent in nature phases, or phases which occur only in inaccessible places, such as the earth core (Manghnani et al., 1980). The use of pressure as a parameter in the study of materials was pioneered principally by Professor P. W. Bridgman, who for forty years investigated most of the elements and many other materials using diverse techniques (Bridgman, 1964). There are many design solutions to ensure High Pressure - High Temperature (HPHT) conditions for obtaining and examination of materials. Depending on the design assumptions, it is possible to achieve very high pressures, up to several hundred gigapascals, as in the case of Diamond Anvils Cell (DAC). 
Such devices, due to their small size, are intended solely for laboratory investigations (XRD in-situ study, neutron diffraction etc.) (Piermarini, 2008). For the purposes of industrial and semi-industrial production of materials the most frequently the "Belt" or "Bridgman" type of equipment is used (Eremets, 1996; Hall, 1960; Khvostantsev et al., 2004). These apparatuses provide a relatively large working volume, the optimum pressure distribution and the possibility of achieving high temperatures.

In the toroidal type of Bridgman apparatus the quasi-hydrostatic compression of the material is achieved as a result of plastic deformation of the so called "gasket" (Fig. 2).

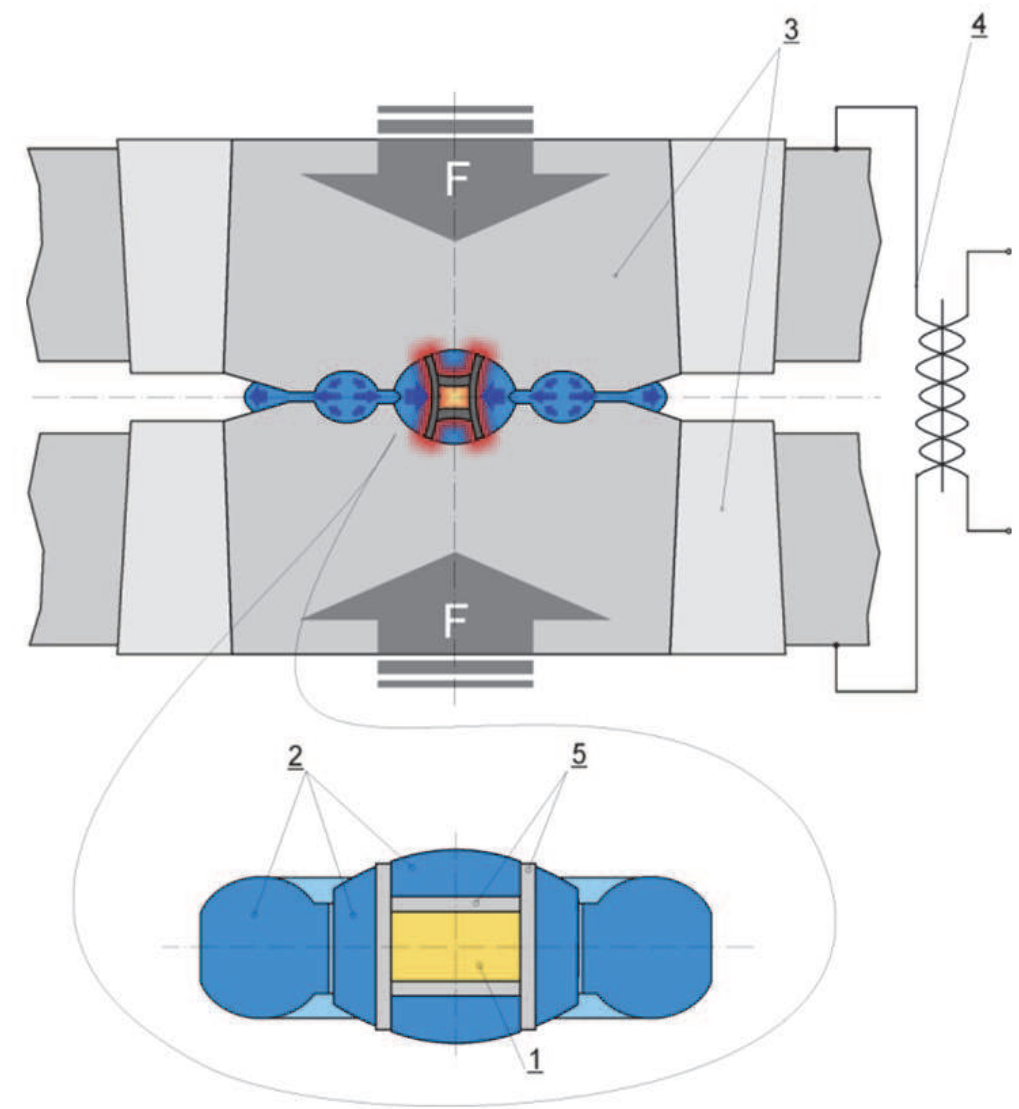

Fig. 2. Sintering process in a Bridgman-type HPHT system. Quasi-hydrostatic compression of the preliminary consolidated powders (sample -1) is achieved as a result of plastic deformation of the gasket material (2) between anvils (3); electrical heating is provided by a high-power transformer (4) and graphite resistive heater (5)

Gaskets are made of special kinds of metamorphic rocks such as pyrophyllite, "lithographic stone" or catlinite (Filonenko \& Zibrov, 2001; Prikhna, 2008). The toroidal chamber,

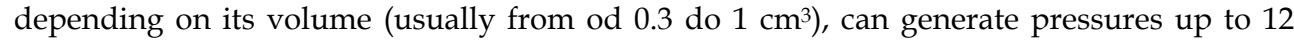
GPa and temperature up to $\sim 2500{ }^{\circ} \mathrm{C}$. The presented system is used often for production of 
synthetic diamonds and for sintering of wide range of superhard composites based on polycrystalline diamond (PCD) or polycrystalline cubic boron nitride (PcBN). Under the influence of a simultaneous action of pressure and temperature the sintering process occurs much faster than in the case of free sintering. A typical duration of sintering process with HPHT method is about 0.5-2 minutes (Fig. 3) while the free sintering requires several hours. Short duration of the process contributes to the grain growth limitation, which is essential in the case of sintering of nanopowdes. The materials obtained with HPHT method are characterized by almost a $100 \%$ level of densification, isotropy of properties and sometimes by a completely different phase composition in relation to the same free-sintered materials, due to the different thermodynamic conditions of the manufacturing process.

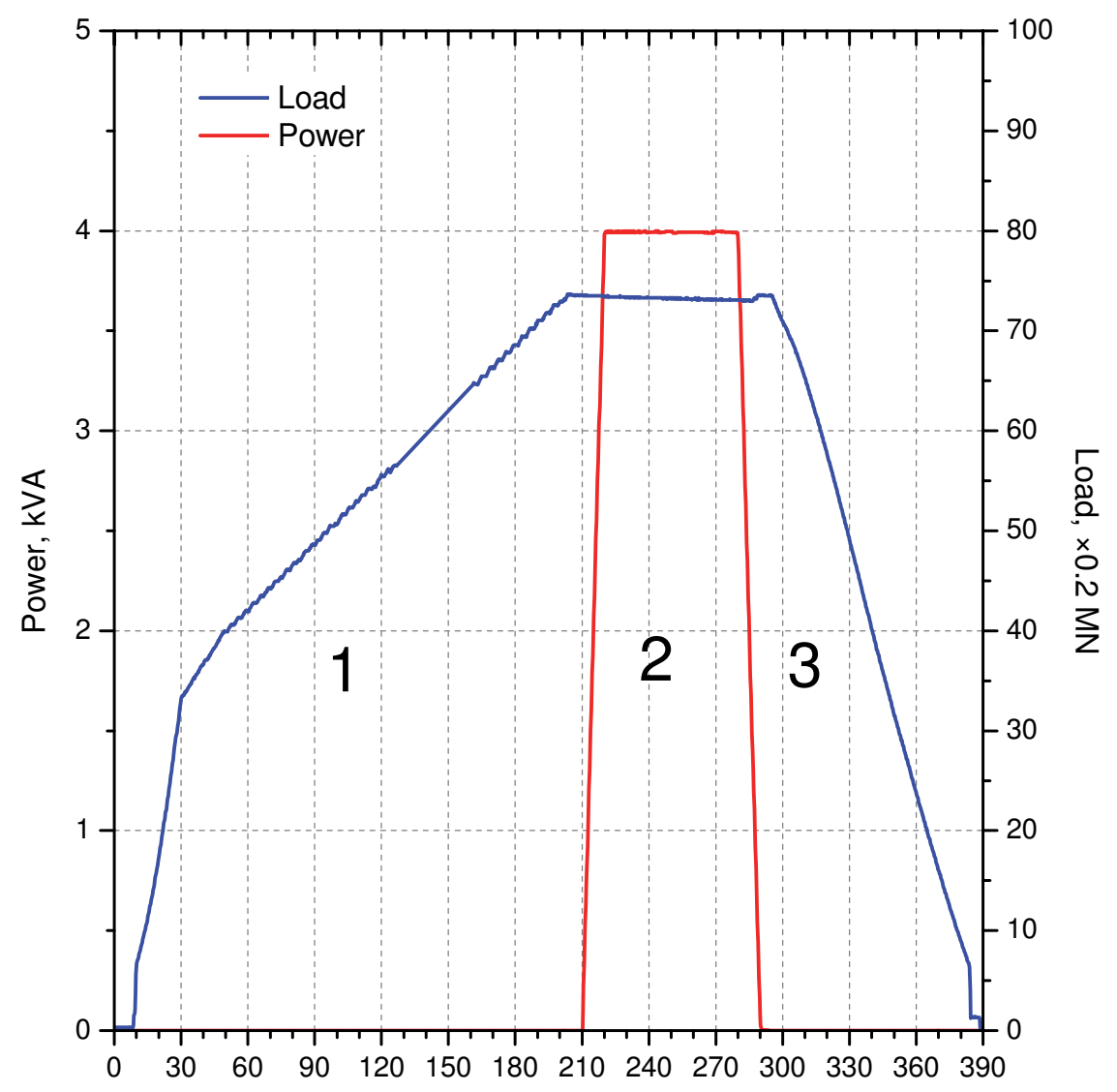

Time, s

Fig. 3. Three stages of an example process of HPHT sintering: 1 - loading, 2 - sintering, 3 - unloading 


\subsection{Samples preparation}

Powders used for the preparation of mixtures for sintering of $\mathrm{SiC} / \mathrm{Si}_{3} \mathrm{~N}_{4}$ materials are listed in Table 1.

\begin{tabular}{|l|l|l|l|l|}
\hline Powder & Category & $\begin{array}{l}\text { Particle size } \\
{[\mu \mathrm{m}]}\end{array}$ & Manufacturer & Description \\
\hline $\mathrm{SiC}$ & nano & $<5 \mathrm{~nm}$ & France & beta \\
\hline $\mathrm{SiC}$ & sub-micro & $0.1-1$ & Goodfellow, UK & alpha \\
\hline $\mathrm{SiC}$ & micro & 1.2 & AGH, Poland & \\
\hline $\mathrm{Si}_{3} \mathrm{~N}_{4}$ & nano & $<20 \mathrm{~nm}$ & Goodfellow, UK & amorphous \\
\hline $\mathrm{Si}_{3} \mathrm{~N}_{4}$ & sub-micro & $0.1-0.8$ & Goodfellow, UK & alpha \\
\hline $\mathrm{Si}_{3} \mathrm{~N}_{4}$ & sub-micro & 0.6 & H.C. Starck, Germany & alpha $>90 \%$, M11-grade \\
\hline $\mathrm{Si}_{3} \mathrm{~N}_{4}$ & micro & $1-5$ & AEE, USA & alpha $>85 \%$ \\
\hline $\mathrm{TiH}_{2}$ & micro & $<44$ & Fluka, Switzerland & \\
\hline $\mathrm{TiB}_{2}$ & micro & $2.5-3.5$ & H.C. Starck, Germany & F-grade \\
\hline cBN & nano & $0-0.1$ & Element6, South Africa & Micron+ABN, M0.10-grade \\
\hline cBN & micro & $3-6$ & Element6, South Africa & Micron+ABN, M36-grade \\
\hline
\end{tabular}

Table 1. Powders used for preparation of mixtures for sintering of $\mathrm{SiC} / \mathrm{Si}_{3} \mathrm{~N}_{4}$ materials

The following mixtures were prepared by mixing the appropriate powders (Table. 1) in an isopropanol environment using the Fritsch Pulverisette 6 planetary mill.

\section{nano-SiC/Si $\mathbf{S}_{3}$ materials}

$100 \% \mathrm{SiC}$ (nano)

$100 \% \mathrm{Si}_{3} \mathrm{~N}_{4}$ (nano)

$50 \mathrm{SiC}$ (nano) $/ 50 \mathrm{Si}_{3} \mathrm{~N}_{4}$ (nano) - vol.\%

sub-micro-SiC/Si ${ }_{3} \mathrm{~N}_{4}$ materials

$95 \mathrm{SiC}$ (sub-micro)/ $5 \mathrm{Si}_{3} \mathrm{~N}_{4}$ (sub-micro, Starck) - vol.\%

$70 \mathrm{SiC}$ (sub-micro)/30 $\mathrm{Si}_{3} \mathrm{~N}_{4}$ (sub-micro, Starck) - vol.\%

$50 \mathrm{SiC}$ (sub-micro)/50 $\mathrm{Si}_{3} \mathrm{~N}_{4}$ (sub-micro, Starck) - vol.\%

$100 \% \mathrm{Si}_{3} \mathrm{~N}_{4}$ (sub-micro, Starck)

\section{micro-SiC/Si ${ }_{3} \mathrm{~N}_{4}$ materials}

$70 \mathrm{SiC}$ (micro)/30 $\mathrm{Si}_{3} \mathrm{~N}_{4}$ (micro) - vol.\%

$100 \% \mathrm{Si}_{3} \mathrm{~N}_{4}$ (micro)

$70 \mathrm{SiC} / 30 \mathrm{Si}_{3} \mathrm{~N}_{4}$ composite (modification by using various $\mathrm{SiC}$ and $\mathrm{Si}_{3} \mathrm{~N}_{4}$ powders)

$70 \mathrm{SiC}$ (sub-micro)/30 $\mathrm{Si}_{3} \mathrm{~N}_{4}$ (sub-micro, Starck) - vol.\%

$70 \mathrm{SiC}$ (sub-micro)/30 $\mathrm{Si}_{3} \mathrm{~N}_{4}$ (sub-micro, Goodfellow) - vol.\%

$70 \mathrm{SiC}$ (micro) $/ 30 \mathrm{Si}_{3} \mathrm{~N}_{4}$ (micro) - vol. \%

$70 \mathrm{SiC}$ (sub-micro)/30 $\mathrm{Si}_{3} \mathrm{~N}_{4}$ (micro) - vol.\%

70SiC/30Si $\mathrm{N}_{4}$ composite $+\mathrm{Ti}$ (modification by addition of the third, metallic phase)

$70 \mathrm{SiC}$ (sub-micro)/30 $\mathrm{Si}_{3} \mathrm{~N}_{4}$ (sub-micro, Starck) +8 vol. $\% \mathrm{Ti}$ - from $\mathrm{TiH}_{2}$ (micro)

$70 \mathrm{SiC} / 30 \mathrm{Si}_{3} \mathrm{~N}_{4}$ composite $+\mathrm{TiB}_{2}$ (modification by addition of the third, boride phase)

$70 \mathrm{SiC}$ (sub-micro)/30 $\mathrm{Si}_{3} \mathrm{~N}_{4}$ (sub-micro, Starck) +8 vol. $\% \mathrm{TiB}_{2}$ (micro)

$70 \mathrm{SiC}$ (sub-micro)/30 $\mathrm{Si}_{3} \mathrm{~N}_{4}$ (sub-micro, Starck) +30 vol. $\% \mathrm{TiB}_{2}$ (micro) 
70SiC/30Si $\mathbf{i}_{3} \mathrm{~N}_{4}$ composite $+\mathbf{c B N}$ (modification by addition of the third, nitride phase)

$70 \mathrm{SiC}$ (sub-micro) $/ 30 \mathrm{Si}_{3} \mathrm{~N}_{4}$ (sub-micro, Starck) +8 vol. $\%$ cBN(micro)

$70 \mathrm{SiC}$ (sub-micro) $/ 30 \mathrm{Si}_{3} \mathrm{~N}_{4}$ (sub-micro, Goodfellow) +8 vol.\% cBN(nano)

$70 \mathrm{SiC}$ (sub-micro)/30 $\mathrm{Si}_{3} \mathrm{~N}_{4}$ (sub-micro, Starck) +30 vol. \% cBN(micro)

After drying, the mixtures were preliminarily compressed into a disc of $\mathrm{r} 15 \mathrm{~mm}$ diameter and $5 \mathrm{~mm}$ height under pressure of $\sim 200 \mathrm{MPa}$. The green bodies with the addition of $\mathrm{TiH}_{2}$ were additionally annealed in a vacuum at a temperature of $800^{\circ} \mathrm{C}$ for $1 \mathrm{~h}$ in order to remove the hydrogen and obtain pure metallic titanium. The materials were obtained at high pressure (6 GPa) in the wide range of temperatures $\left(430-2150{ }^{\circ} \mathrm{C}\right.$ depending of composition) using a Bridgman-type toroidal apparatus (Fig. 2). The sintering temperatures were established experimentally for each material to obtain crack-free samples with the highest values of density and mechanical properties. The duration of the sintering process was 40 s for nanopowders and $60 \mathrm{~s}$ for the others.

The sintered compacts were subsequently ground to remove remains of graphite after the technological process of sintering and to obtain the required quality and surface parallelism for Young's modulus determination. The samples provided for microscopic investigations and for mechanical tests were additionally polished using diamond slurries.

\subsection{Investigation methods}

Densities of the sintered samples were measured by the hydrostatic method. The uncertainty of the measurements was below $0.02 \mathrm{~g} / \mathrm{cm}^{3}$, which gave a relative error value of below $0.5 \%$ (excluding measurements of small pieces of broken samples, where the error was up to $0.1 \mathrm{~g} / \mathrm{cm}^{3}$, due to their insufficient volume and mass).

Young's modulus of the samples obtained by HPHT sintering was measured by means of transmission velocity of ultrasonic waves through the sample, using a Panametrics Epoch III ultrasonic flaw detector. Calculations were carried out according to (Eq. 1):

$$
E=\rho \cdot C_{T}^{2} \frac{3 C_{L}^{2}-4 C_{T}^{2}}{C_{L}^{2}-C_{T}^{2}}
$$

where: $E$ - Young's modulus, $C_{L}$ - velocity of the longitudinal wave, $C_{T}$ - velocity of the transversal wave, $\rho$ - density of the material.

The velocities of transverse and longitudinal waves were determined as a ratio of sample thickness and relevant transition time. The accuracy of calculated Young's modulus (Eq. 1) was estimated to be below $2 \%$.

Hardness of sintered samples was determined by the Vickers method using a digital Vickers Hardness Tester (FUTURE-TECH FV-700). Five hardness measurements, with indentation loads of 2.94, 9.81 and $98.1 \mathrm{~N}$, were carried out for each sample. Standard deviations of HV values were relatively high but usually no more than $5 \%$ of the average values.

Indentation fracture toughness was calculated from the length of cracks which developed in a Vickers indentation test (with indentation load - 98.1 N) using Niihara's equation (Eq. 2):

$$
\frac{K_{I c} \varphi}{H \sqrt{a}}\left(\frac{H}{E \varphi}\right)^{\frac{2}{5}}=0.129 \cdot\left(\frac{c}{a}\right)^{-\frac{3}{2}}
$$


where: $K_{I c}$ - critical stress intensity factor, $\varphi$ - constrain factor, $H$ - Vickers hardness, $E$ - Young's modulus, $a$ - half of indent diagonal, $c$ - length of crack.

Microstructural observations were carried out on the densified materials using a JEOL JXA50A Scanning electron Microscope equipped with back scattering electron (BSE) imaging. In the Ball-On-Disc tests, the coefficient of friction and the specific wear rate of the sintered samples in contact with $\mathrm{Si}_{3} \mathrm{~N}_{4}$ ball were determined using a CETR UMT-2MT (USA) universal mechanical tester. In the Ball-On-Disc method, sliding contact is brought about by pushing a ball specimen onto a rotating disc specimen under a constant load (Fig. 4). The loading mechanism applied a controlled load $F_{n}$ to the ball holder and the friction force was measured continuously during the test using an extensometer. For each test, a new ball was used or the ball was rotated so that a new surface was in contact with the disc. The ball and disc samples were washed in ethyl alcohol and dried.

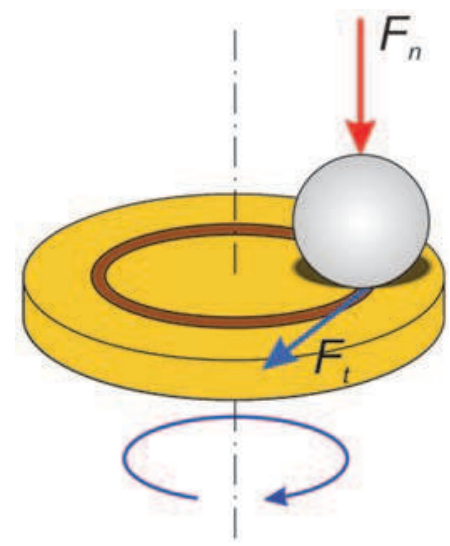

Fig. 4. Material pair for the Ball-On-Disc method: $1-\mathrm{Si}_{3} \mathrm{~N}_{4}$ ball; 2 - sample (disc)

The size of the disc-shaped samples was $\sim 13.5$ in diameter and $\sim 3.8 \mathrm{~mm}$ in height with the surfaces flatness and parallelism within $0.02 \mathrm{~mm}$. The roughness of the tested surface was not more than $0.1 \mu \mathrm{m} \mathrm{R}$. The following test conditions were established: ball diameter - 2 $\mathrm{mm}$, applied load $-4 \mathrm{~N}$, sliding speed $-0.1 \mathrm{~m} / \mathrm{s}$, diameter of the sliding circle $-2 \div 5 \mathrm{~mm}$, sliding distance $-100 \mathrm{~m}$, calculated duration of the test $-1000 \mathrm{~s}$. The tests were carried out without lubricant at room temperature. Each test was repeated at least three times. Coefficient of friction was calculated from (Eq. 3):

$$
\mu=\frac{F_{f}}{F_{n}}
$$

where: $\mu$ - coefficient of friction, $F_{f}$ - measured friction force, $F_{n}$ - applied normal force.

After completing the test, according to ISO 20808:2004 E standard, the cross-sectional profile of the wear track at four places at intervals of $90^{\circ}$ was measured using a contact stylus profilometer PRO500 (CETR, USA). Then the average cross-sectional area of the wear track was calculated. The volume of material removed was calculated as a product of crosssectional area of the wear track and their circumference. Specific wear rate was calculated from (Eq. 4): 


$$
W_{s}=\frac{V}{F_{n} \cdot L}
$$

where: $W_{s}$ - specific wear rate, $V$ - volume of removed material, $L$ - sliding distance.

\section{Materials sintered from nano-, sub-micro-, and micro-SiC/Si $\mathrm{S}_{3} \mathrm{~N}_{4}$ powders}

A macroscopic view, phase composition and crystallite size of materials sintered from nanopowders under the pressure of $6 \mathrm{GPa}$ at temperatures ranging from 430 to $1880^{\circ} \mathrm{C}$ in the period of time 40 s are shown in Table 2.

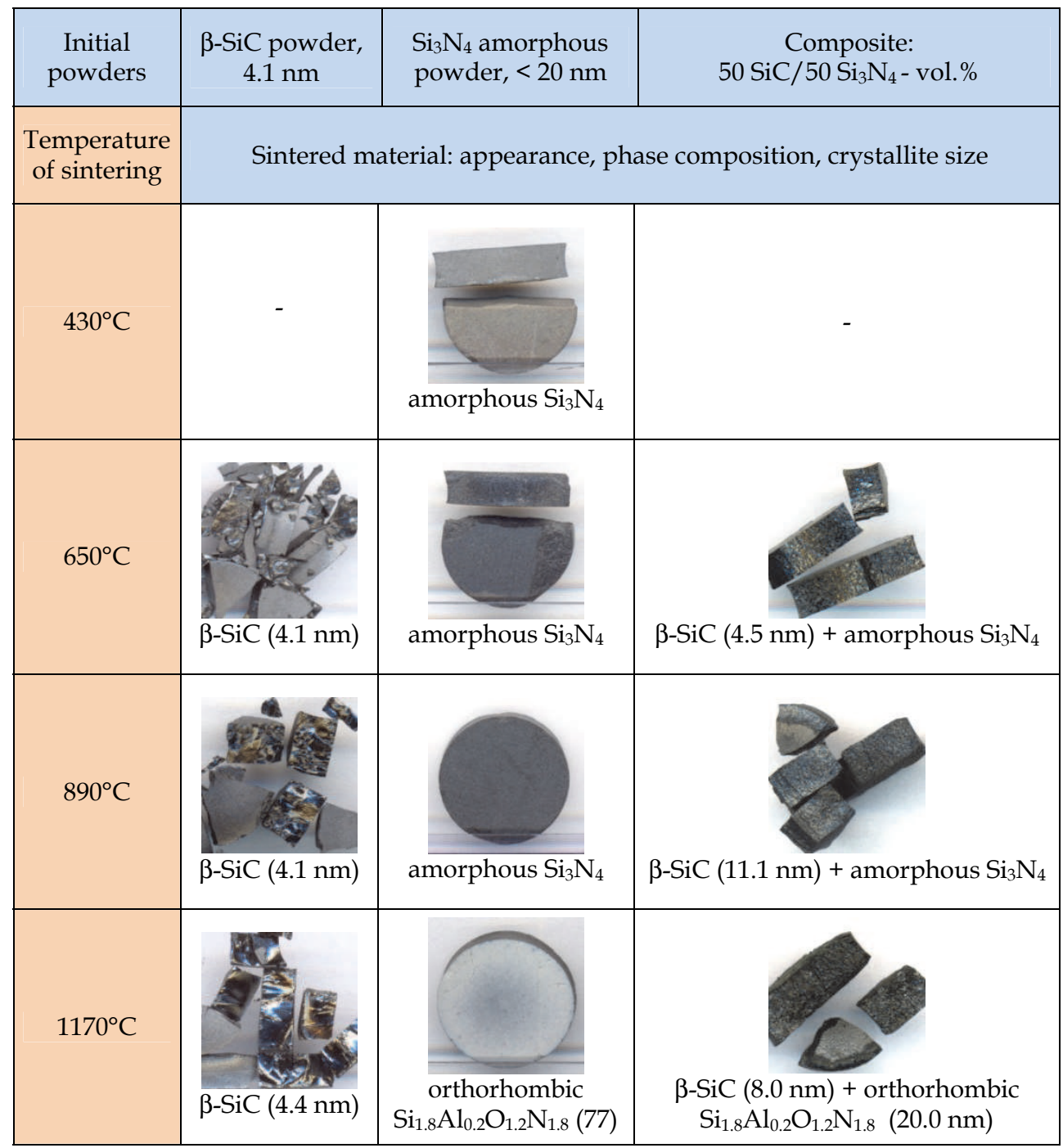




\begin{tabular}{|c|c|c|c|}
\hline $\begin{array}{l}\text { Initial } \\
\text { powders }\end{array}$ & $\begin{array}{c}\beta \text {-SiC powder, } \\
4.1 \mathrm{~nm}\end{array}$ & $\begin{array}{l}\mathrm{Si}_{3} \mathrm{~N}_{4} \text { amorphous } \\
\text { powder, }<20 \mathrm{~nm}\end{array}$ & $\begin{array}{c}\text { Composite: } \\
50 \mathrm{SiC} 50 \mathrm{Si}_{3} \mathrm{~N}_{4}-\text { vol. } \%\end{array}$ \\
\hline $\begin{array}{l}\text { Temperature } \\
\text { of sintering }\end{array}$ & \multicolumn{3}{|c|}{ Sintered material: appearance, phase composition, crystallite size } \\
\hline $1450^{\circ} \mathrm{C}$ & $\beta-\operatorname{SiC}(10.6 \mathrm{~nm})$ & $\beta-\mathrm{Si}_{3} \mathrm{~N}_{4}(77.4 \mathrm{~nm})$ & $\begin{array}{l}\beta-\mathrm{SiC}(10.2 \mathrm{~nm})+\text { orthorhombic } \\
\mathrm{Si}_{1.8} \mathrm{Al}_{0.2} \mathrm{O}_{1.2} \mathrm{~N}_{1.8}(31.0 \mathrm{~nm})\end{array}$ \\
\hline $1880^{\circ} \mathrm{C}$ & $\beta-\operatorname{SiC}(110 \mathrm{~nm})$ & $\beta-\mathrm{Si}_{3} \mathrm{~N}_{4}(143 \mathrm{~nm})$ & $\beta-\operatorname{SiC}(51.8 \mathrm{~nm})+\beta-\mathrm{Si}_{3} \mathrm{~N}_{4}(86.9 \mathrm{~nm})$ \\
\hline
\end{tabular}

Table 2. A macroscopic view, phase composition and crystallite size of $\mathrm{SiC} / \mathrm{Si}_{3} \mathrm{~N}_{4}$ materials sintered from nanopowders under the pressure of $6 \mathrm{GPa}$ at temperatures ranging from 430 to $1880^{\circ} \mathrm{C}$ in the period of time $40 \mathrm{~s}$

The initial crystallite size of sintered $\mathrm{SiC}$ nanopowder was about $4.1 \mathrm{~nm}$ and did not change until the sintering temperature of $1170^{\circ} \mathrm{C}$. At the sintering temperature of $1450^{\circ} \mathrm{C}$ crystallites reached an average size of $10.6 \mathrm{~nm}$ while at the maximum applied temperature $\left(1880^{\circ} \mathrm{C}\right)$ their size was $110 \mathrm{~nm}$. This material showed no phase transformation. The sinters obtained at $1880^{\circ} \mathrm{C}$ as well as the initial powder have the cubic structure of $\beta$-SiC phase.

Sintered $\mathrm{Si}_{3} \mathrm{~N}_{4}$ powder remained amorphous until the temperature of $890{ }^{\circ} \mathrm{C}$. At the temperature of $1170{ }^{\circ} \mathrm{C}$ a new phase crystallized. The X-ray diffraction pattern of this phase corresponds to the o'-sialon with orthorhombic structure and $\mathrm{Si}_{1.8} \mathrm{Al}_{0.2} \mathrm{O}_{1.2} \mathrm{~N}_{1.8}$ stoichiometry. As evidenced by the chemical formula, this compound has a low content of aluminum with reference to silicon while the quantities of nitrogen and oxygen are comparable. It can be assumed that $\mathrm{o}^{\prime}$-sialon is a transition phase between the amorphous silicon nitride and a completely crystalline $\beta-\mathrm{Si}_{3} \mathrm{~N}_{4}$ phase. O'-sialon was formed probably due to embedding a certain amount of oxygen and impurities adsorbed on the surface of powder to an atomic lattice of crystallizing silicon nitride. The crystallite size of this phase was estimated to around be $77 \mathrm{~nm}$. The samples obtained at temperatures of 1450 and $1880{ }^{\circ} \mathrm{C}$ contain only $\beta$ $\mathrm{Si}_{3} \mathrm{~N}_{4}$ phase with the crystallite size 77.4 and $143 \mathrm{~nm}$ respectively.

$50 \mathrm{SiC} / 50 \mathrm{Si}_{3} \mathrm{~N}_{4}$ - vol.\% nanocomposite was sintered at the same temperatures as silicon carbide powder without additions. The phase composition of sintered composites did not differ qualitatively from the sum of their components sintered separately. There was no formation of new phases in the reaction between silicon carbide and silicon nitride. Sintering of composites, especially at higher temperatures, leads to lower grain growth than it is in single-phase powders sintered separately. This indicates a favorable effect of inhibiting grain growth in the composite. 
The comparison of physical-mechanical properties of nano-, sub-micro- and micro-SiC/ $\mathrm{Si}_{3} \mathrm{~N}_{4}$ materials sintered at different temperatures is presented in Fig. 5 and Table 3. Generally, nanocomposites are characterized by the lowest physical-mechanical properties of the three granulometric types of the investigated materials. Densities and Young's modulus values of the best nanostructured samples do not exceed $2.55 \mathrm{~g} / \mathrm{cm}^{3}$ and $135 \mathrm{GPa}$ respectively. In most cases, nanostructured $\mathrm{SiC} / \mathrm{Si}_{3} \mathrm{~N}_{4}$ samples are characterized by a lot of cracks (see Table 2). Cracking of such ceramics occurs as a result of the presence in their structure of residual micro- and macro-stresses which overcome the strength of the produced material. The fine powder is characterized by a very large specific surface and high gas content in the sample due to the absorption process of the material particles. During heating, as a result of the increase in temperature, the volume of gases increases, which causes cracking or even permanent fragmentation of the sample. In order to prevent the cracking phenomena in the samples, various conditions of the sintering process were tested. Depending on composition, materials characterized by the highest level of densification and the best mechanical properties were obtained at different temperatures: $890{ }^{\circ} \mathrm{C}$ for pure $\mathrm{Si}_{3} \mathrm{~N}_{4}$ and $1880{ }^{\circ} \mathrm{C}$ for $50 \mathrm{Si}_{3} \mathrm{~N}_{4} / 50 \mathrm{SiC}$ - vol.\% composite. Unfortunately, some of these samples had cracks as well. Different kinds of internal cracks, delamination and other defects of microstructure occurred in most of the nanostructured samples. These defects cause a scattering of caustic waves propagated through the material and, in consequence, the impossibility of Young's modulus measurements using ultrasonic probes (marked as **nm in Table 3).

Composites without cracks were obtained only from micro- and sub-micro-structured powders. Only for these composites hardness and fracture toughness were measured.
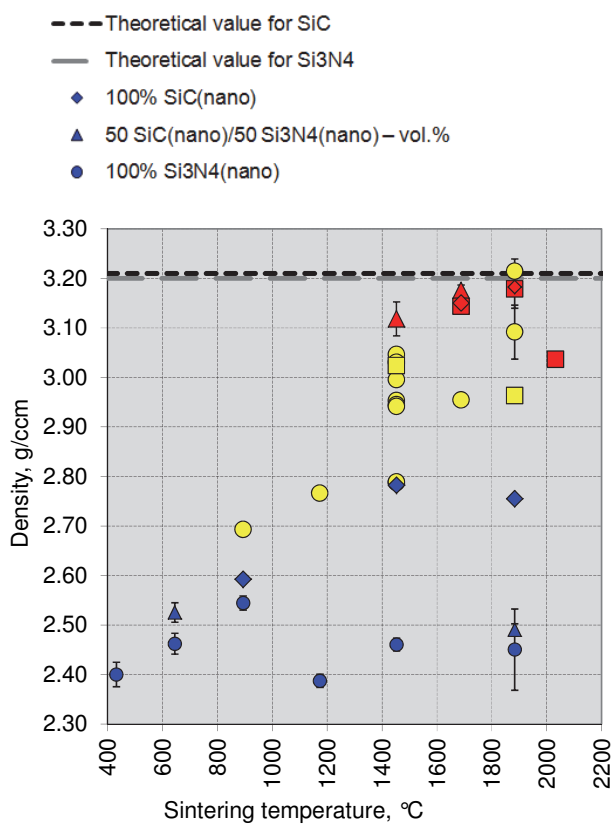

- $95 \mathrm{SiC}($ sub-micro)/5 Si3N4(sub-micro, Starck)-vol.\%

- $70 \mathrm{SiC}($ sub-micro)/30 Si3N4(sub-micro, Starck)-vol.\%

$\Delta 50 \mathrm{SiC}$ (sub-micro)/50 Si3N4(sub-micro, Starck)-vol.\%

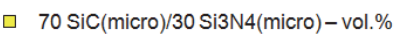

- $100 \%$ Si3N4(micro)

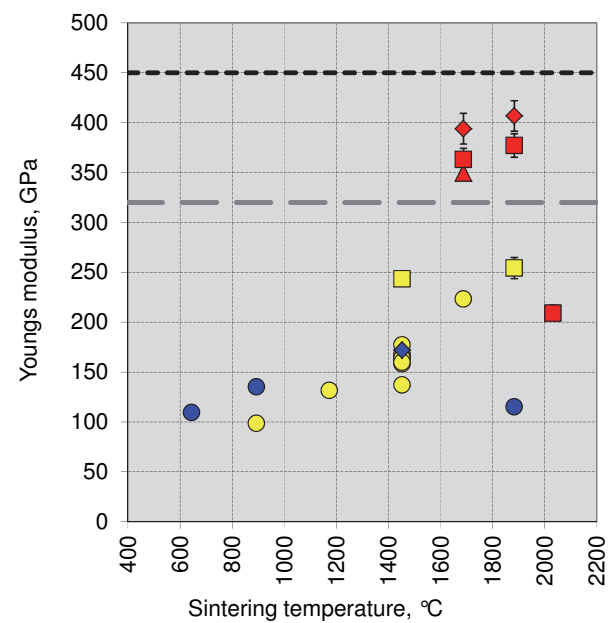

Fig. 5. Density and Young modulus of nano-, sub-micro-, and micro-SiC/Si $\mathrm{Si}_{3} \mathrm{~N}_{4}$ materials sintered at different temperatures 


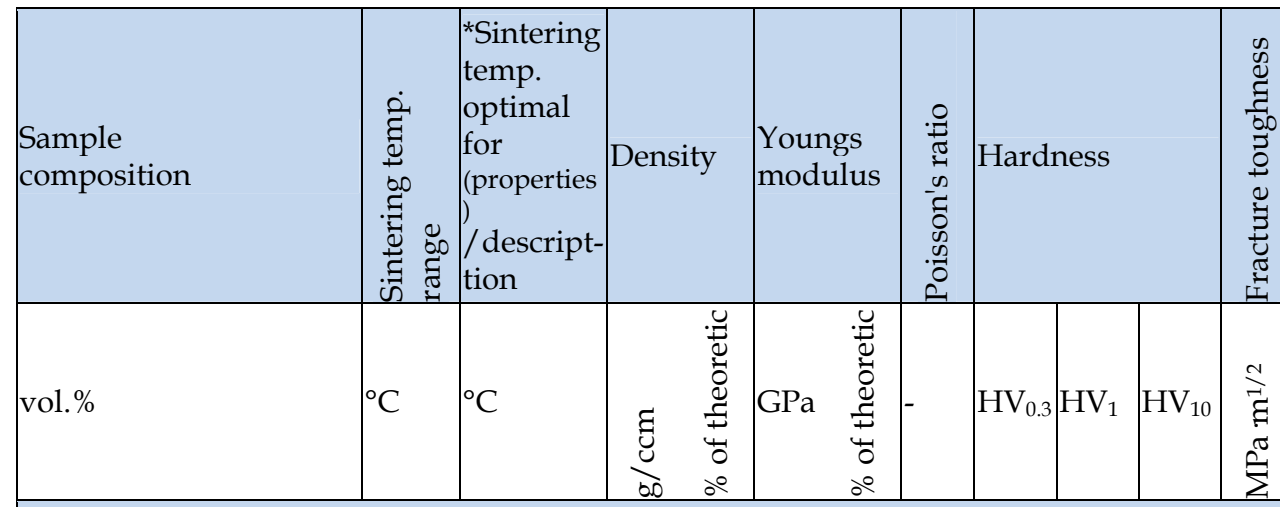

nanomaterials (initial powders: $\beta-\mathrm{SiC}<5 \mathrm{~nm}$, amorphous $\mathrm{Si}_{3} \mathrm{~N}_{4}<20 \mathrm{~nm}$ ) sintered at $6 \mathrm{GPa}$ for 40 s

\begin{tabular}{|l|l|l|ll|ll|l|l|l|l|l|}
\hline $100 \mathrm{SiC}($ nano) & $\begin{array}{l}650- \\
1880\end{array}$ & $\begin{array}{l}1450 \\
/ \text { cracks }\end{array}$ & 2.78 & 87 & 172 & 38 & 0.24 & - & - & - & - \\
\hline $\begin{array}{l}50 \mathrm{SiC}(\text { nano) } \\
/ 50 \mathrm{Si}_{3} \mathrm{~N}_{4} \text { (nano) }\end{array}$ & $\begin{array}{l}650- \\
1880\end{array}$ & $\begin{array}{l}1880 \\
\text { / small } \\
\text { chipping }\end{array}$ & 2.49 & 78 & $* * \mathrm{~nm}-$ & $* * \mathrm{~nm}$ & - & - & - & - \\
\hline $100 \mathrm{Si}_{3} \mathrm{~N}_{4}$ (nano) & $\begin{array}{l}430- \\
1880\end{array}$ & 890 & 2.54 & 80 & 135 & 42 & 0.24 & - & - & - & - \\
\hline
\end{tabular}

sub-micro-structured materials (powders: $\alpha-\mathrm{SiC} 0.1-1 \mu \mathrm{m}, \alpha-\mathrm{Si}_{3} \mathrm{~N}_{4} 0.6 \mu \mathrm{m}$ ) sintered at $6 \mathrm{GPa}$ for 60 s

\begin{tabular}{|c|c|c|c|c|c|c|c|c|c|c|c|}
\hline $\begin{array}{l}95 \mathrm{SiC} \text { (sub-micro) } \\
/ 5 \mathrm{Si}_{3} \mathrm{~N}_{4} \text { (sub-micro, Starck) }\end{array}$ & $\begin{array}{l}1690- \\
2150\end{array}$ & $\begin{array}{l}1880 \\
/ \text { cracks }\end{array}$ & 3.18 & 99 & 407 & 92 & 0.17 & - & - & - & - \\
\hline \multirow{2}{*}{$\begin{array}{l}70 \mathrm{SiC}_{\text {(sub-micro) }} \\
/ 30 \mathrm{Si}_{3} \mathrm{~N}_{4} \text { (sub-micro, Starck) }\end{array}$} & \multirow{2}{*}{$\begin{array}{l}1690- \\
2030\end{array}$} & $\begin{array}{l}* 1690 \\
(K I c)\end{array}$ & 3.14 & 98 & 363 & 87 & 0.19 & 2810 & 2630 & 2240 & 5.6 \\
\hline & & $\begin{array}{l}{ }^{*} 1880(\rho, \\
E, H V)\end{array}$ & 3.18 & 99 & 377 & 90 & 0.19 & 3130 & 2970 & 2400 & 4.9 \\
\hline $\begin{array}{l}50 \mathrm{SiC} \text { (sub-micro) } \\
/ 50 \mathrm{Si}_{3} \mathrm{~N}_{4} \text { (sub-micro, Starck) }\end{array}$ & $\begin{array}{l}1450- \\
1880\end{array}$ & 1690 & 3.18 & 99 & 349 & 91 & 0.21 & 2700 & 2560 & 2140 & 5 \\
\hline $100 \mathrm{Si}_{3} \mathrm{~N}_{4}$ (sub-micro, Starck) & $\begin{array}{l}1170- \\
1690\end{array}$ & /cracs & - & - & - & - & - & - & - & - & - \\
\hline
\end{tabular}

micro-structured materials (initial powders: $\mathrm{SiC} 1.2 \mu \mathrm{m}, \alpha-\mathrm{Si}_{3} \mathrm{~N}_{4} 1-5 \mu \mathrm{m}$,) sintered at $6 \mathrm{GPa}$ for 60 s

\begin{tabular}{|c|c|c|c|c|c|c|c|c|c|c|}
\hline $\begin{array}{l}70 \mathrm{SiC} \text { (micro) } \\
/ 30 \mathrm{Si}_{3} \mathrm{~N}_{4} \text { (micro) }\end{array}$ & $\begin{array}{l}1450- \\
1880\end{array}$ & $\begin{array}{l}1450 \\
\text { / small } \\
\text { cracks }\end{array}$ & 3.0294 & 243 & 58 & 0.16 & - & 1880 & 1510 & 4.6 \\
\hline \multirow[b]{2}{*}{$100 \mathrm{Si}_{3} \mathrm{~N}_{4}$ (micro) } & \multirow[b]{2}{*}{$\begin{array}{l}890- \\
1880\end{array}$} & ${ }^{*} 1450(\rho)$ & $3.03 \quad 95$ & 167 & 52 & 0.2 & - & 1250 & 1060 & 4.8 \\
\hline & & $\begin{array}{l}* 1690(E) \\
\text { small } \\
\text { chipping }\end{array}$ & 2.9592 & 223 & 70 & 0.22 & & - & - & - \\
\hline
\end{tabular}

Table 3. Physical-mechanical properties of selected nano-, sub-micro- and micro-SiC/ $\mathrm{Si}_{3} \mathrm{~N}_{4}$ materials sintered at optimal temperatures; *optimum temperature for selected properties, e.g. $1690\left(K_{I c}\right)$ - the best fracture toughness; ${ }^{* *} \mathrm{~nm}$ - non measurable with ultrasonic method 


\begin{tabular}{|c|c|c|c|c|c|c|c|c|c|}
\hline & \multicolumn{4}{|c|}{$\mathrm{Si}_{3} \mathrm{~N}_{4}$ based ceramics } & \multicolumn{3}{|c|}{ SiC based ceramics } & \multirow{2}{*}{\multicolumn{2}{|c|}{$\begin{array}{c}\text { Sub-micro- } \\
70 \mathrm{SiC} / 30 \mathrm{Si}_{3} \mathrm{~N}_{4} \\
\text { composites } \\
\text { (this work) }\end{array}$}} \\
\hline & 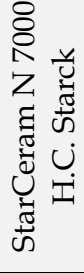 & 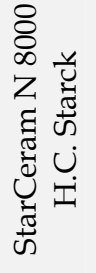 & 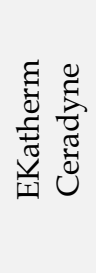 & 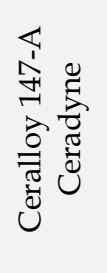 & 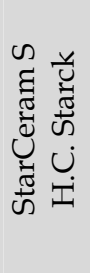 & 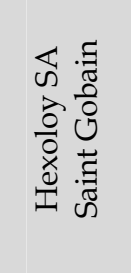 & 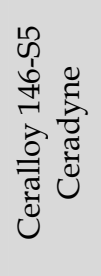 & & \\
\hline $\begin{array}{c}\text { Density, } \\
\mathrm{g} / \mathrm{ccm}\end{array}$ & $>3.22$ & $>3.23$ & $>3.24$ & 3.18 & 3.10 & 3.10 & 3.20 & 3.14 & 3.18 \\
\hline $\begin{array}{c}\text { Young's } \\
\text { modulus, } \\
\text { GPa }\end{array}$ & 290 & 310 & 310 & 310 & 395 & 410 & 430 & 363 & 377 \\
\hline $\begin{array}{c}\text { Vickers } \\
\text { hardness, } \\
\text { HV }\end{array}$ & 1500 & 1520 & $\begin{array}{c}1450 \\
(300 \mathrm{~g})\end{array}$ & $\begin{array}{l}1650 \\
(300 \mathrm{~g})\end{array}$ & 2500 & $\begin{array}{c}2800 \\
(100 \mathrm{~g} \\
\text { Konopp } \\
) \\
\end{array}$ & $\begin{array}{c}2600 \\
(300 g)\end{array}$ & $\begin{array}{c}2812 \\
(300 \mathrm{~g})\end{array}$ & $\begin{array}{c}3132 \\
(300 \mathrm{~g} \\
)\end{array}$ \\
\hline $\begin{array}{l}\text { Fracture } \\
\text { toughness, } \\
\mathrm{MPa}^{1 / 2} \mathrm{~m}^{1 / 2}\end{array}$ & 6.7 & 6.0 & 7.0 & 4.5 & 3.0 & 4.6 & 4.3 & 5.6 & 4.9 \\
\hline
\end{tabular}

Table 4. Comparison of commercial advanced $\mathrm{SiC} / \mathrm{Si}_{3} \mathrm{~N}_{4}$-based ceramics ${ }^{1}$ with sub-microstructured $70 \mathrm{SiC} / 30 \mathrm{Si}_{3} \mathrm{~N}_{4}$ - vol.\% composites obtained by HPHT sintering

The composites obtained from submicron powders are characterized by the best properties. Density and Young's modulus of the best $70 \mathrm{SiC} / 30 \mathrm{Si}_{3} \mathrm{~N}_{4}-$ vol.\% compacts sintered at 1880 ${ }^{\circ} \mathrm{C}$ were $3.18 \mathrm{~g} / \mathrm{cm}^{3}$ and $377 \mathrm{GPa}$ respectively (over $99 \%$ and $90 \%$ of the theoretical values). This material is also characterized by the highest hardness (HV1 3000) and relatively good fracture toughness $\left(4.9 \mathrm{MPa} \mathrm{m}^{1 / 2}\right)$. The same material sintered at a lower temperature $(1690$ ${ }^{\circ} \mathrm{C}$ ) has slightly lower values of density $\left(3.14 \mathrm{~g} / \mathrm{cm}^{3}\right)$, Young's modulus (363 GPa) and hardness (HV1 2626) but higher fracture toughness (5.6 MPa $\mathrm{m}^{1 / 2}$ ) - Table 3. HPHT sintered sub-micro-70 SiC/30 $\mathrm{Si}_{3} \mathrm{~N}_{4}$ - vol.\% composites have a better combination of mechanical properties than comparable commercial materials (Table 4).

The composites obtained from the micro-sized powders have their properties intermediate between the nano- and sub-micro-structured materials. Even though the best micro-SiC/Si $3 \mathrm{~N}_{4}$ samples are crack free and have fairly good density (>94\% of theoretical values) and indentation fracture toughness $\left(4.6-4.8 \mathrm{MPa} \mathrm{m}^{1 / 2}\right)$, their Young's modulus and hardness are much lower than for the sub-micro-structured samples. The insufficient mechanical properties of microstructured $\mathrm{Si}_{3} \mathrm{~N}_{4}-\mathrm{SiC}$ materials can be attributed not only to grain size but also to specific properties of the initial powder resulting from their production method (e.g. shape of the grains, impurities, oxidation etc.). The choice of suitable initial powders for the given method of sintering is the critical factor in achieving good quality of ceramics.

\footnotetext{
${ }^{1}$ Data from: H.C. Starck Ceramics GmbH\& Co. KG, Ceradyne Inc. and Saint - Gobain Advanced Ceramics - commercial data sheets)
} 
For all the investigated samples, independently of their grain size, a strong influence of indentation load on hardness values can be observed. Increasing the indentation load causes a decrease in hardness values (Table 3 ).

\section{Modifications of $70 \mathrm{SiC} / 30 \mathrm{Si}_{3} \mathrm{~N}_{4}$ composite}

Density and Young's modulus of various $70 \mathrm{SiC} / 30 \mathrm{Si}_{3} \mathrm{~N}_{4}-$ vol.\% composites sintered at different temperatures with and without additions of $\mathrm{Ti}, \mathrm{TiB}_{2}$ and $\mathrm{cBN}$ phases are presented in Figs 6-11 and in Table 5.

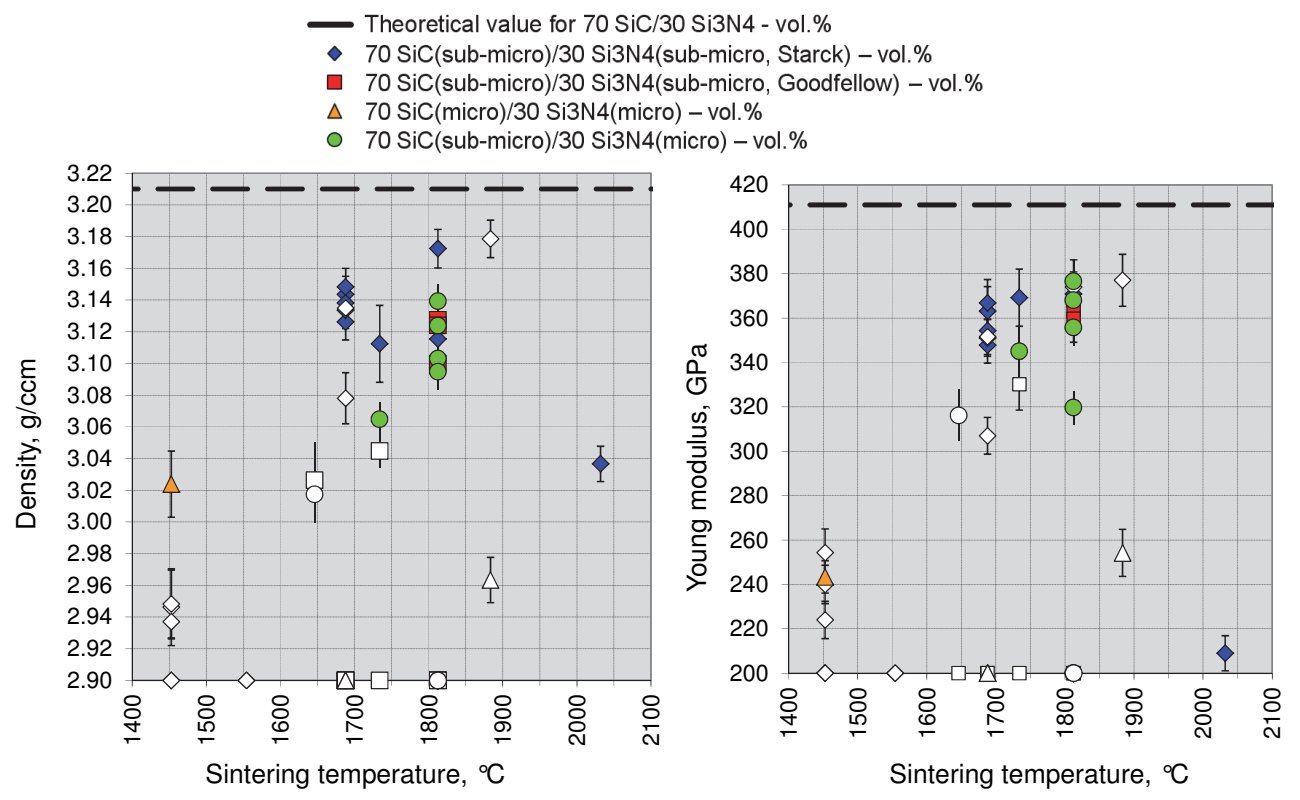

Fig. 6. Density and Young's modulus of various kinds of $70 \mathrm{SiC} / 30 \mathrm{Si}_{3} \mathrm{~N}_{4}-$ vol.\% composites sintered at different temperatures. Colored symbols - samples without cracks; white symbols - samples with cracks; white symbols placed on temperature axis - broken samples 


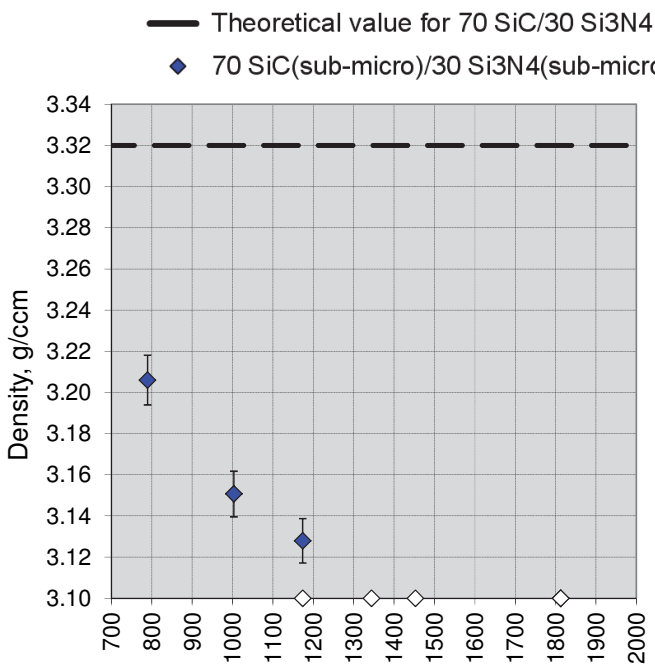

Sintering temperature, ${ }^{\circ} \mathrm{C}$

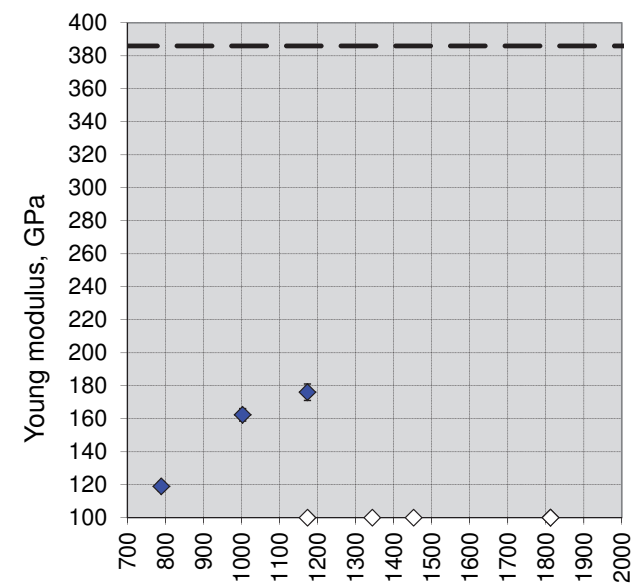

Sintering temperature, ${ }^{\circ} \mathrm{C}$

Fig. 7. Density and Young's modulus of $70 \mathrm{SiC} / 30 \mathrm{Si}_{3} \mathrm{~N}_{4}+8$ vol.\% Ti composites sintered at different temperatures. Dark symbols - samples without cracks; white symbols - samples with cracks; white symbols placed on temperature axis - broken samples

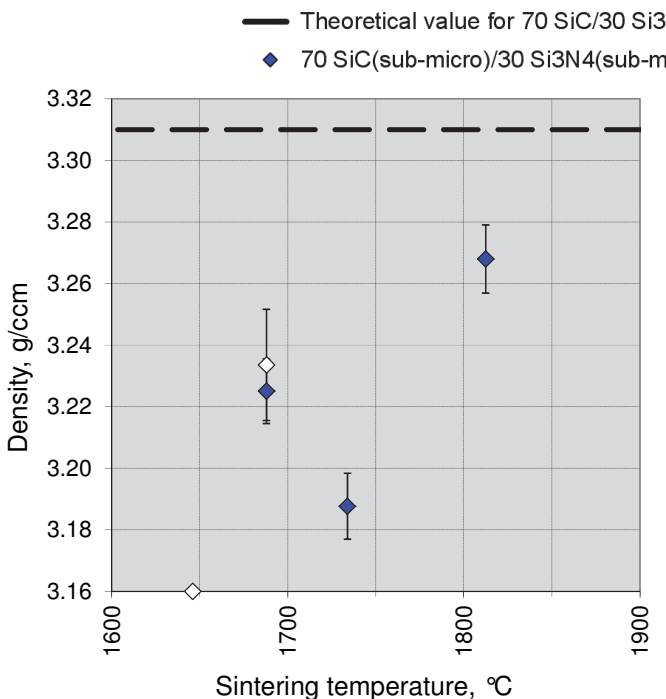

micro, Starck) +8 vol. $\%$ TiB2 $($ micro)
TiB2

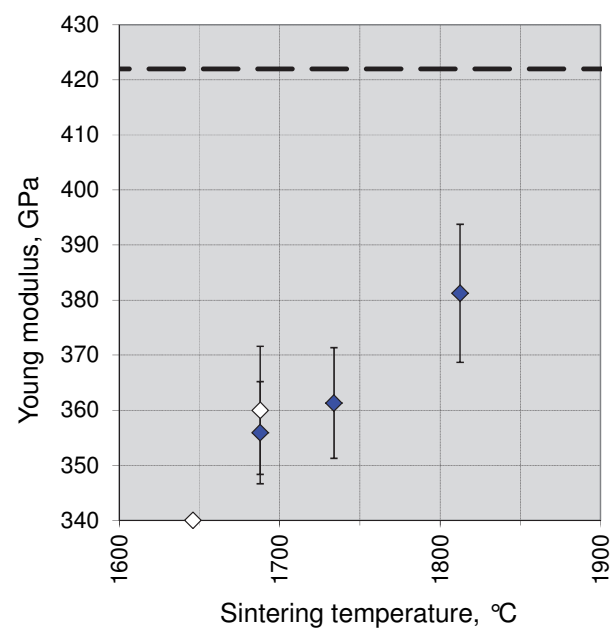

Fig. 8. Density and Young's modulus of $70 \mathrm{SiC} / 30 \mathrm{Si}_{3} \mathrm{~N}_{4}+8$ vol. $\% \mathrm{TiB}_{2}$ composites sintered at different temperatures. Dark symbols - samples without cracks; white symbols - samples with cracks; white symbols placed on temperature axis - broken samples 
- Theoretical value for $70 \mathrm{SiC} / 30 \mathrm{Si} 3 \mathrm{~N} 4+30$ vol. \% TiB2

• $70 \mathrm{SiC}($ sub-micro)/30 Si3N4(sub-micro, Starck)+ 30 vol. \% TiB2(micro)
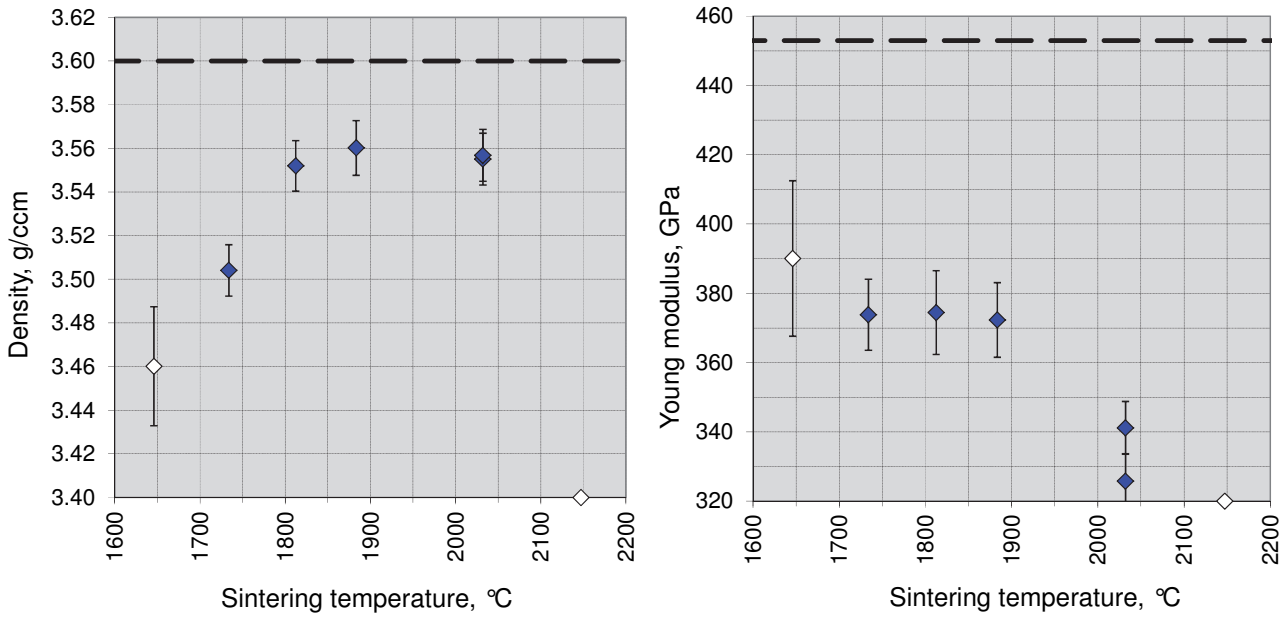

Fig. 9. Density and Young's modulus of $70 \mathrm{SiC} / 30 \mathrm{Si}_{3} \mathrm{~N}_{4}+30$ vol. $\% \mathrm{TiB}_{2}$ composites sintered at different temperatures. Dark symbols - samples without cracks; white symbols - samples with cracks; white symbols placed on temperature axis - broken samples

- Theoretical value for $70 \mathrm{SiC} / 30 \mathrm{Si} 3 \mathrm{~N} 4+8$ vol.\% cBN

$\checkmark 70 \mathrm{SiC}$ (sub-micro)/30 Si3N4 (sub-micro, Starck) + 8 vol.\% cBN(micro)

$70 \mathrm{SiC}$ (sub-micro)/30 Si3N4 (sub-micro, Goodfellow) + 8 vol.\% cBN(nano)
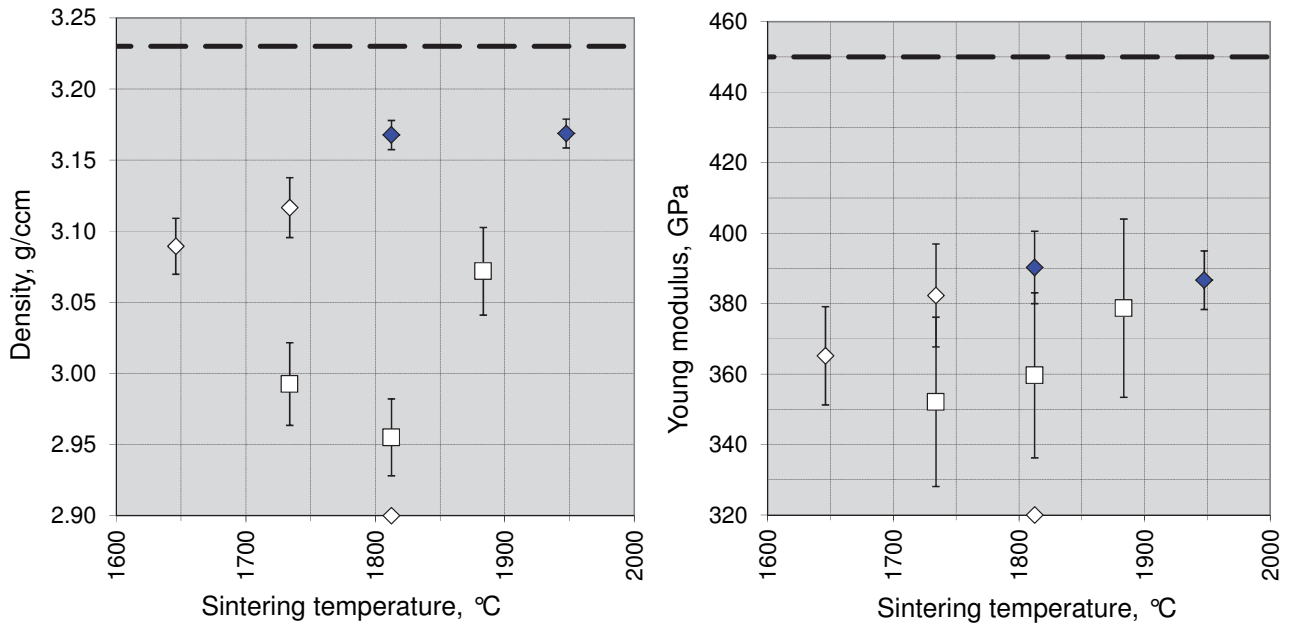

Fig. 10. Density and Young's modulus of $70 \mathrm{SiC} / 30 \mathrm{Si}_{3} \mathrm{~N}_{4}+8$ vol. $\%$ cBN composites sintered at different temperaturesDark symbols - samples without cracks; white symbols - samples with cracks; white symbols placed on temperature axis - broken samples 

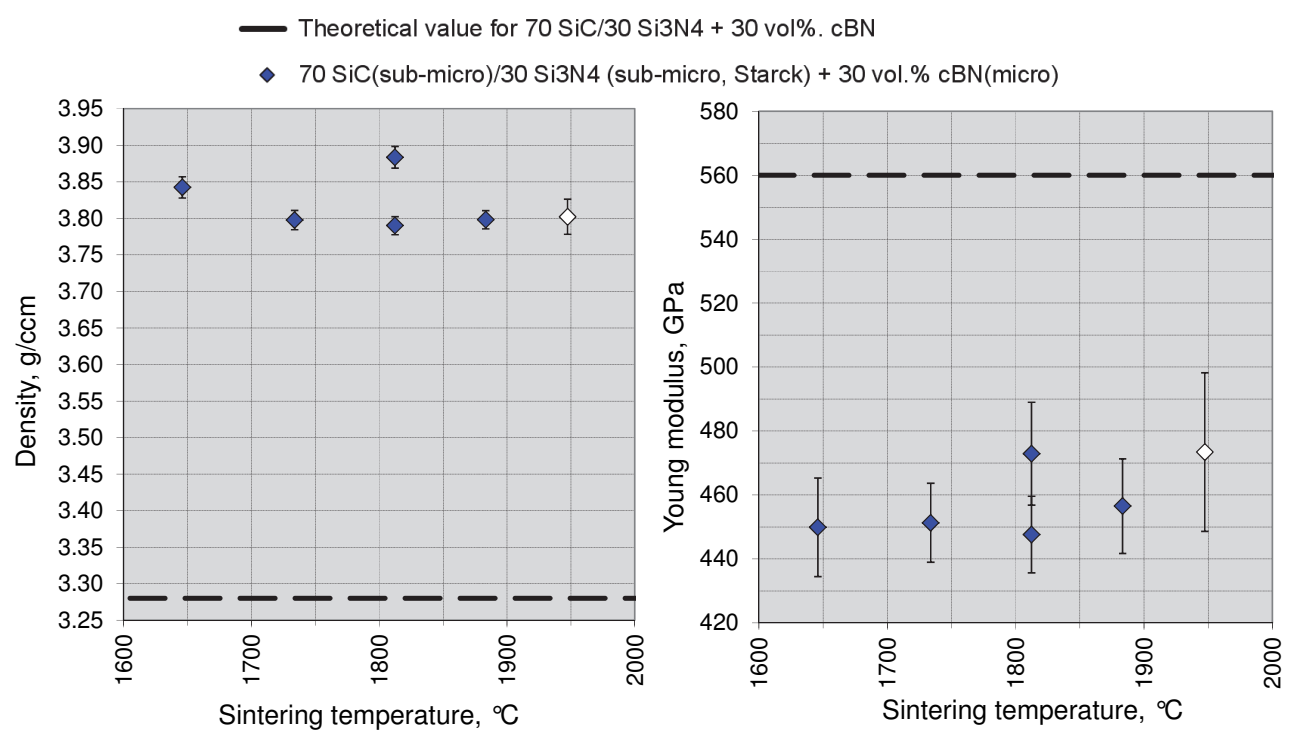

Fig. 11. Density and Young's modulus of $70 \mathrm{SiC} / 30 \mathrm{Si}_{3} \mathrm{~N}_{4}+30$ vol. $\%$ cBN composites sintered at different temperatures. Dark symbols - samples without cracks; white symbols samples with cracks

Among the composites sintered without additional phases, the highest degree of densification and best mechanical properties were demonstrated by composite obtained from submicron powders $70 \mathrm{SiC}$ (sub-micro)/30 $\mathrm{Si}_{3} \mathrm{~N}_{4}$ (sub-micro, Starck) - vol\%. (Fig. 6 and Table 5). This composite was selected for modification by the addition of the third phase particles.

The modification of the $70 \mathrm{SiC} / 30 \mathrm{Si}_{3} \mathrm{~N}_{4}$ composite by the addition of Ti was not successful. The samples with the addition of 8 vol.\% Ti introduced in the form of $\mathrm{TiH}_{2}$, sintered at low temperatures, were characterized by a very low Young's modulus, whilst all the samples sintered at temperatures above $\sim 1200{ }^{\circ} \mathrm{C}$ were cracked. A decrease in density was observed with increasing sintering temperature, whilst Young's modulus showed an upward trend (Fig. 7).

The composites with the addition of $\mathrm{TiB}_{2}$ were characterized by a high degree of densification, a high Young's modulus and improved $\mathrm{K}_{\mathrm{Ic}}$ as compared to the unmodified composite. No improvement in hardness was observed (Table 5). In the case of $70 \mathrm{SiC} / 30 \mathrm{Si}_{3} \mathrm{~N}_{4}$ material with the addition of $8 \mathrm{vol} . \% \mathrm{TiB}_{2}$, there is some increase in density and Young's modulus with increasing temperature (Fig. 8). Composite with the addition of 30 vol. $\% \mathrm{TiB}_{2}$, shows an increase in density with sintering temperature up to a maximum value, and then its stabilization. A further increase of the sintering temperature results in cracking of the samples (Fig. 9).

The composites modified by the addition of 8 vol.\% cBN micropowder have better properties than the composites with $\mathrm{TiB}_{2}$ but a tendency to cracking of this material is noticeable. The use of nano-cBN particles as a modifier causes the deterioration of the properties and cracking of samples (Fig. 10). The composites modified by the addition of 30 vol.\% cBN micropowder, showed the best mechanical properties (Fig. 11 and Table 5). 


\begin{tabular}{|c|c|c|c|c|c|c|c|c|c|c|}
\hline Sample composition & 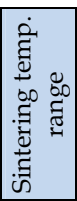 & $\begin{array}{c}\text { Sintering } \\
\text { temp. } \\
\text { optimal for } \\
\text { (properties) } \\
\text { / descrip } \\
\text { tion }\end{array}$ & Der & sity & $\begin{array}{l}\text { Yo } \\
\text { mo }\end{array}$ & $\begin{array}{ll}\operatorname{lig} \\
\text { igs }\end{array}$ & 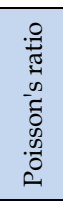 & Har & ness & 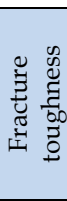 \\
\hline vol. $\%$ & ${ }^{\circ} \mathrm{C}$ & ${ }^{\circ} \mathrm{C}$ & $\frac{\tilde{g}}{0.0}$ & 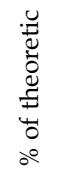 & $\mathrm{GPa}$ & 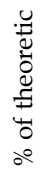 & GPa & $\mathrm{HV}_{1}$ & $\mathrm{HV}_{10}$ & 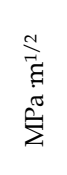 \\
\hline 70SiC/30Si $\mathrm{N}_{4}$ composite & & & & & & & & & & \\
\hline $70 \mathrm{SiC}$ (sub-micro)/ & $1450-$ & $\begin{array}{c}{ }^{*} 1880(\rho, E, \\
H V)\end{array}$ & 3.18 & 99 & 377 & 92 & 0.19 & 2970 & 2400 & 4.9 \\
\hline & & ${ }^{*} 1690\left(K_{I c}\right)$ & 3.14 & 98 & 363 & 87 & 0.19 & 2630 & 2240 & 5.6 \\
\hline $\begin{array}{l}70 \mathrm{SiC} \text { (sub-micro)/ } \\
30 \mathrm{Si}_{3} \mathrm{~N}_{4} \text { (sub-micro, oodfellow) }\end{array}$ & $\begin{array}{l}1650- \\
1810\end{array}$ & $\begin{array}{l}1810 \\
\text { /cracks }\end{array}$ & 3.13 & 97 & 368 & 89 & 0.20 & 2772 & 2268 & 5.7 \\
\hline $\begin{array}{l}70 \mathrm{SiC}_{(\text {micro }) /} \\
30 \mathrm{Si}_{3} \mathrm{~N}_{4} \text { (micro) }\end{array}$ & $\begin{array}{c}1450- \\
1880 \\
\end{array}$ & $\begin{array}{c}1450 / \text { small } \\
\text { cracks }\end{array}$ & 3.02 & 94 & 243 & 58 & 0.16 & 1880 & 1510 & 4.6 \\
\hline $70 \mathrm{SiC}$ (sub-micro)/ & $1650-$ & $\begin{array}{c}* 1810(\rho, E, \\
H V)\end{array}$ & 3.10 & 97 & 368 & 90 & 0.20 & 2748 & 2392 & 5.6 \\
\hline $30 \mathrm{Si}_{3} \mathrm{~N}_{4}$ (micro) & 1810 & \begin{tabular}{|c|}
$1730\left(K_{I c}\right)$ \\
$/$ small cracks
\end{tabular} & 3.06 & 95 & 345 & 84 & 0.20 & 2576 & 2278 & 6.0 \\
\hline 70SiC/30Si $\mathrm{N}_{4}$ composite $+\mathrm{Ti}$ & & & & & & & & & & \\
\hline $70 \mathrm{SiC}$ (sub-micro)/ & $790-$ & *790 $(\rho)$ & 3.21 & 97 & 119 & 31 & 0.13 & - & - & - \\
\hline $\begin{array}{l}30 \mathrm{Si}_{3} \mathrm{~N}_{4} \text { (sub-micro, Starck) } \\
+8 \mathrm{Ti} \text { - from } \mathrm{TiH}_{2} \text { (micro) }\end{array}$ & 1810 & ${ }^{*} 1170(E)$ & 3.13 & 94 & 176 & 46 & 0.10 & - & - & - \\
\hline $70 \mathrm{SiC}_{3} 30 \mathrm{Si}_{3} \mathrm{~N}_{4}$ composite $+\mathrm{TiB}_{2}$ & & & & & & & & & & \\
\hline $70 \mathrm{SiC}$ (sub-micro)/ & 1650 & ${ }^{*} 1810(\rho, E)$ & 3.27 & 99 & 381 & 90 & 0.20 & 2488 & 2364 & 4.2 \\
\hline $\begin{array}{l}30 \mathrm{Si}_{3} \mathrm{~N}_{4} \text { (sub-micro, Starck) } \\
+8 \mathrm{TiB}_{2} \text { (micro) }\end{array}$ & 1810 & ${ }^{*} 1690\left(K_{I c}\right)$ & 3.23 & 97 & 356 & 84 & 0.18 & 2526 & 2324 & 6.1 \\
\hline $\begin{array}{l}70 \mathrm{SiC}_{\text {(sub-micro)/ }} \\
30 \mathrm{Si}_{3} \mathrm{~N}_{4} \text { (sub-micro, Starck) }\end{array}$ & 1650- & $\begin{array}{c}{ }^{*} 1810 \\
(\rho, H V)\end{array}$ & 3.55 & 99 & 374 & 83 & 0.17 & 2564 & 2318 & 5.8 \\
\hline$+30 \mathrm{TiB}_{2}$ (micro) & & ${ }^{*} 1730\left(K_{I c}\right)$ & 3.50 & 97 & 374 & 83 & 0.17 & 2390 & 2260 & 6.4 \\
\hline $70 \mathrm{SiC} / 30 \mathrm{Si}_{3} \mathrm{~N}_{4}$ composite $+\mathrm{cBN}$ & & & & & & & & & & \\
\hline $\begin{array}{l}70 \mathrm{SiC}_{(\text {sub-micro }) /} \\
30 \mathrm{Si}_{3} \mathrm{~N}_{4} \text { (sub-micro, Starck) } \\
+8 \mathrm{cBN} \text { (micro) }\end{array}$ & $\begin{array}{l}1650- \\
1950\end{array}$ & $\begin{array}{l}1950 \\
\text { /cracks }\end{array}$ & 3.17 & 98 & 387 & 86 & 0.19 & 2850 & 2408 & 6.4 \\
\hline $\begin{array}{l}70 \mathrm{SiC}_{\text {(sub-micro)/ }} \\
30 \mathrm{Si}_{3} \mathrm{~N}_{4} \text { (sub-micro, Goodfellow) } \\
+8 \mathrm{cBN} \text { (nano) }\end{array}$ & $\begin{array}{l}1730- \\
1880\end{array}$ & $\begin{array}{l}1880 \\
\text { /cracks }\end{array}$ & 3.07 & 95 & 379 & 84 & 0.17 & - & - & - \\
\hline $70 \mathrm{SiC}$ (sub-micro)/ & $1650-$ & $\begin{array}{c}{ }^{*} 1810 \\
(\rho, E) / \text { cracks }\end{array}$ & 3.88 & 118 & 473 & 84 & 0.18 & 3038 & 2612 & 7.4 \\
\hline$+30 \mathrm{cBN}$ (micro) & 1950 & $\begin{array}{c}{ }^{*} 1880 \\
\left(H V, K_{I c}\right)\end{array}$ & 3.80 & 116 & 457 & 82 & 0.18 & 3190 & 2790 & 7.5 \\
\hline
\end{tabular}

Table 5. Physical-mechanical properties of the best samples selected from different modifications of $70 \mathrm{SiC} / 30 \mathrm{Si}_{3} \mathrm{~N}_{4}$ composites; *optimum temperature for selected properties, e.g. $1690\left(K_{I c}\right)$ - the best value of fracture toughness

SEM microstructures of $70 \mathrm{SiC} / 30 \mathrm{Si}_{3} \mathrm{~N}_{4}$ with and without the addition of $\mathrm{TiB}_{2}$ and $c B N$ are presented in Fig. 12. The microstructures of the investigated samples are compact and dense, with the ingredients uniformly distributed in the volume of the composite. This demonstrates successful blending, using a planetary mill; EDS analysis, however, showed a 


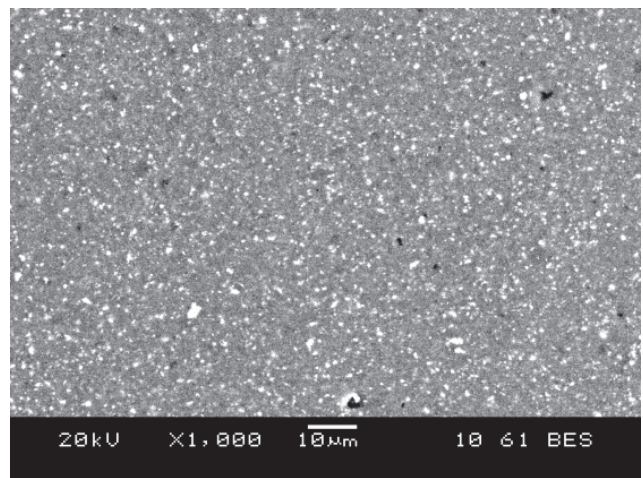

$70 \mathrm{SiC}$ (sub-micro)/30 $\mathrm{Si}_{3} \mathrm{~N}_{4}$ (sub-micro, Starck) - vol.\%

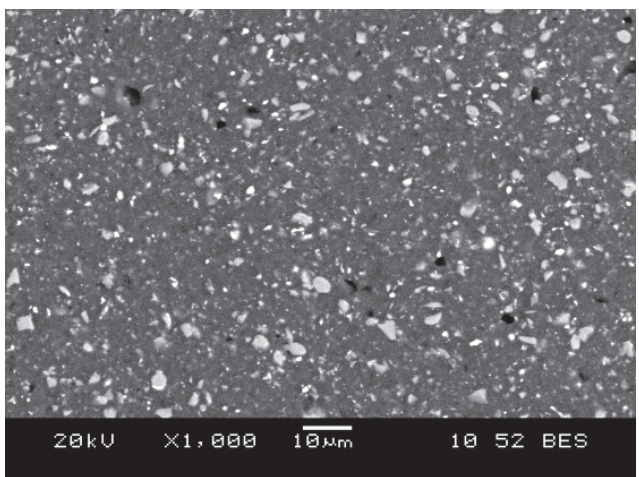

$70 \mathrm{SiC}$ (sub-micro)/30 $\mathrm{Si}_{3} \mathrm{~N}_{4}$ (sub-micro, Starck) +8 vol. $\% \mathrm{TiB}_{2}$ (micro)

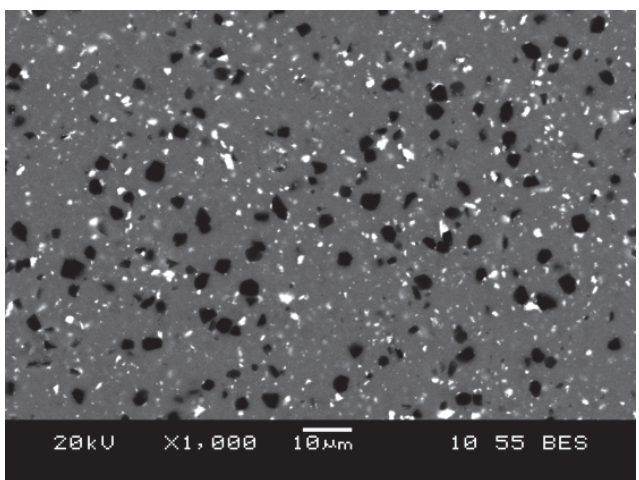

$70 \mathrm{SiC}$ (sub-micro)/30 $\mathrm{Si}_{3} \mathrm{~N}_{4}$ (sub-micro, Starck) +8 vol. $\%$ cBN(micro)

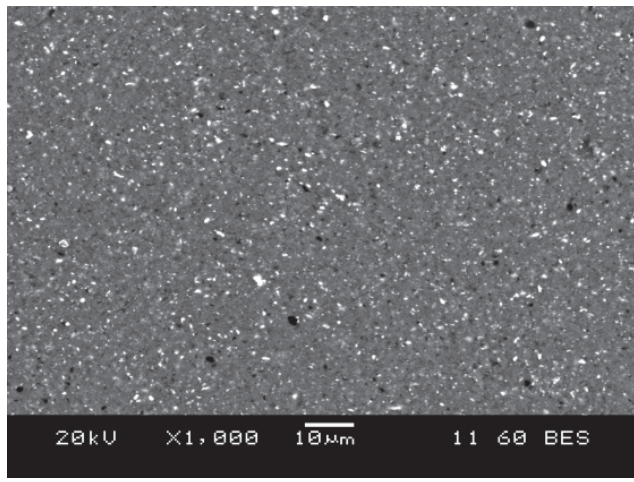

$70 \mathrm{SiC}$ (micro)/30 $\mathrm{Si}_{3} \mathrm{~N}_{4}$ (micro) - vol. $\%$

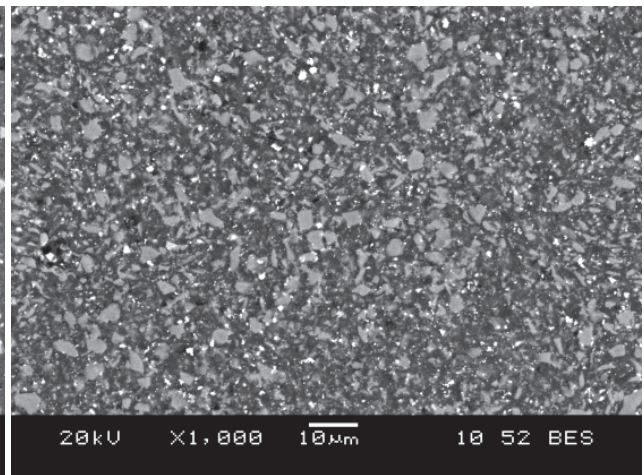

$70 \mathrm{SiC}$ (sub-micro)/30 $\mathrm{Si}_{3} \mathrm{~N}_{4}$ (sub-micro, Starck) +30 vol. $\% \mathrm{TiB}_{2}$ (micro)

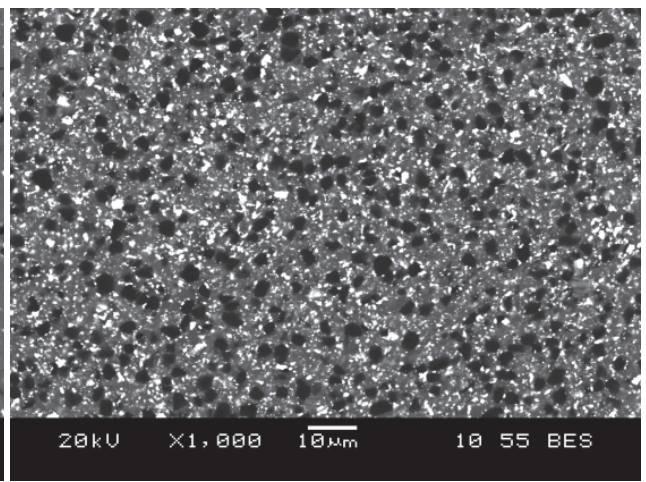

$70 \mathrm{SiC}$ (sub-micro)/30 $\mathrm{Si}_{3} \mathrm{~N}_{4}$ (sub-micro, Starck) +30 vol. \% cBN(micro)

Fig. 12. SEM microstructures of selected $70 \mathrm{SiC} / 30 \mathrm{Si}_{3} \mathrm{~N}_{4}$ composites with and without the addition of $\mathrm{TiB}_{2}$ and $\mathrm{cBN}$ 
high content of tungsten carbide and zirconium dioxide from the vessel and grinding media used to prepare the mixtures (white areas visible in the microstructures - Fig. 12). The highest quantity of WC was admixed to composite containing $30 \%$ of cBN super-abrasive powder. WC has density of $15.7 \mathrm{~g} / \mathrm{cm}^{3}$. It explains too high value $(118 \%)$ of relative density of $70 \mathrm{SiC} / 30 \mathrm{Si}_{3} \mathrm{~N}_{4}+30 \mathrm{vol}$.\% cBN composite.

An example of a crack which developed in a Vickers indentation test in the composite modified by addition $30 \%$ of $c B N$ is presented in Fig. 13. In this material the mixed mode of crack propagation can be observed. Some parts of fracture are of an intra-crystalline character (indicated as $\mathbf{1}$ in Fig. 13) while some are inter-crystalline (indicated as $\mathbf{2}$ in Fig. 13). In both cases the change of direction of crack propagation is visible. A similar effect can be observed in the composites modified by the $\mathrm{TiB}_{2}$ phase. This indicates that the crack deflection mechanism influences on toughening of composites modified by ceramic particles.

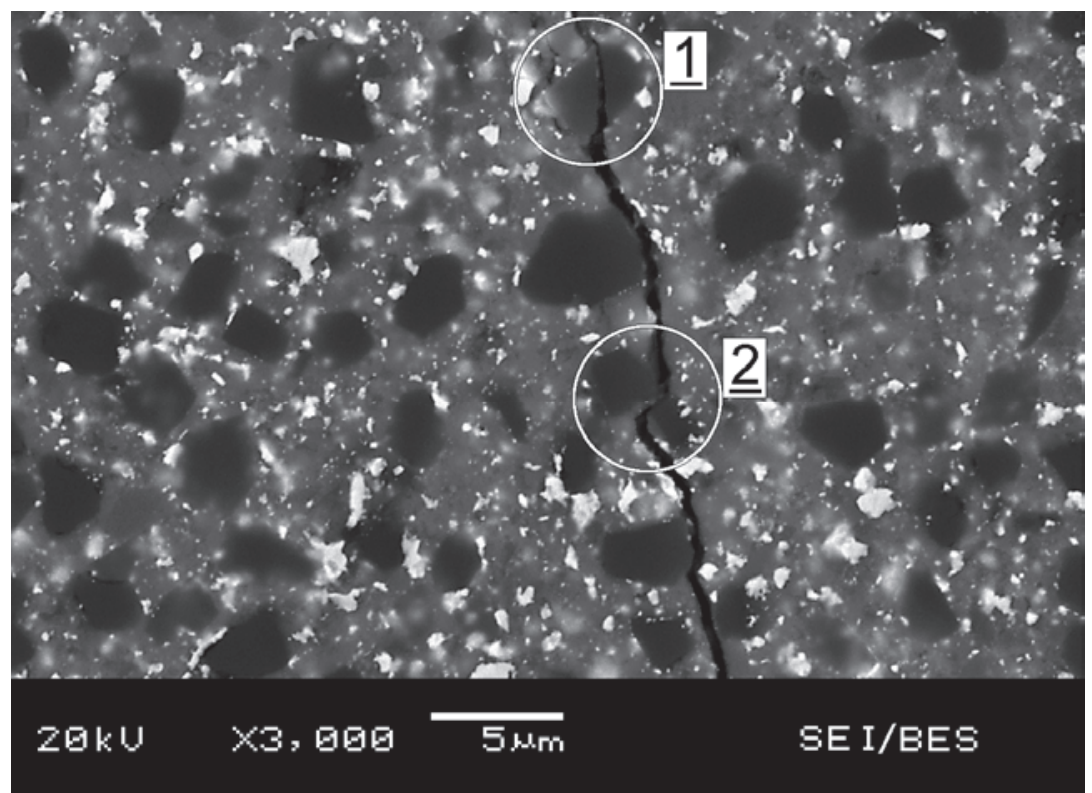

Fig. 13. SEM microstructure of $70 \mathrm{SiC} / 30 \mathrm{Si}_{3} \mathrm{~N}_{4}$ composite modified by addition of $30 \mathrm{vol} . \%$ cBN phase (the darkest areas). Mixed mode of crack propagation visible: 1) crack propagates through the $\mathrm{cBN}$ grains, 2) crack propagates around the $\mathrm{cBN}$ grains

High-quality composites, characterized by the homogeneous microstructure, without cracks (formed during the third stage of HPHT sintering process - cooling and releasing of the pressure) and high values of Young's modulus, hardness and fracture toughness were subjected to the tribological tests. The above criteria were fulfilled for following materials: $70 \mathrm{SiC}$ (sub-micro)/30 $\mathrm{Si}_{3} \mathrm{~N}_{4}$ (sub-micro, Starck) - vol.\%, $70 \mathrm{SiC}$ (sub-micro)/30 $\mathrm{Si}_{3} \mathrm{~N}_{4}$ (micro) - vol.\%, $70 \mathrm{SiC}$ (sub-micro)/30 $\mathrm{Si}_{3} \mathrm{~N}_{4}$ (sub-micro, Starck) + 8 vol.\% $\mathrm{TiB}_{2}$ (micro), $70 \mathrm{SiC}$ (sub-micro)/30 $\mathrm{Si}_{3} \mathrm{~N}_{4}$ (sub-micro, Starck)+ 30 vol. $\% \mathrm{TiB}_{2}$ (micro), $70 \mathrm{SiC}$ (sub-micro)/30 $\mathrm{Si}_{3} \mathrm{~N}_{4}$ (sub-micro, Starck) + 30 vol. \% cBN(micro). 
Additionally, for comparison, the commercial $\mathrm{Si}_{3} \mathrm{~N}_{4}$ based cutting tool material (ISCAR, IS9-grade) was also tested. The mean curves of friction coefficient for investigated materials in a sliding contact with the $\mathrm{Si}_{3} \mathrm{~N}_{4}$ ball are presented in Fig. 14. A comparison of the specific wear rate determined by the wear tracks measurement is presented in Fig. 15.

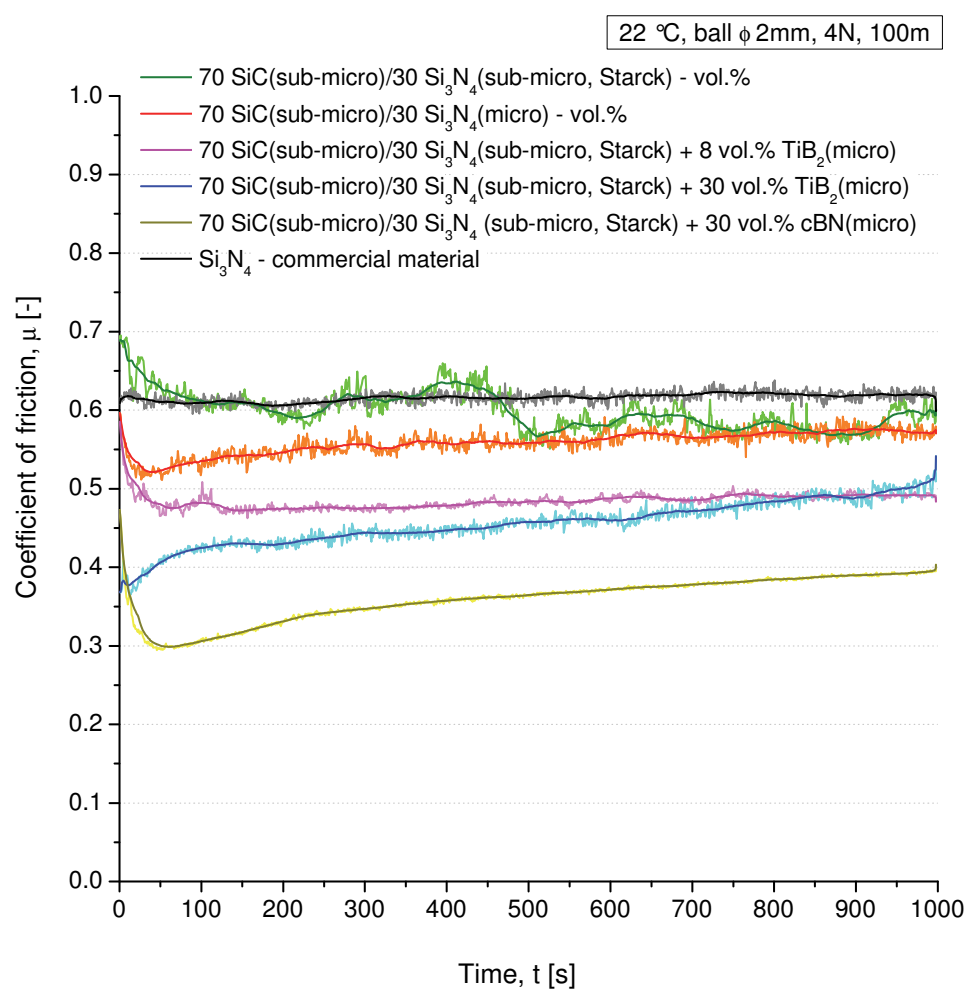

Fig. 14. Coefficient of friction of selected $70 \mathrm{SiC} / 30 \mathrm{Si}_{3} \mathrm{~N}_{4}-$ vol. $\%$ composites with and without the addition of $\mathrm{TiB}_{2}$ and $\mathrm{cBN}$

$70 \mathrm{SiC} / 30 \mathrm{Si}_{3} \mathrm{~N}_{4}$ composites, sintered without additional phases, as well as the commercial material had the highest coefficients of friction. Average values of the friction coefficient for $70 \mathrm{SiC}$ (sub-micro)/30 $\mathrm{Si}_{3} \mathrm{~N}_{4}$ (sub-micro, Starck), $70 \mathrm{SiC}$ (sub-micro)/ $30 \mathrm{Si}_{3} \mathrm{~N}_{4}$ (micro) composites and for commercial $\mathrm{Si}_{3} \mathrm{~N}_{4}$ based cutting tool material were 0.60, 0.56 and 0.62 respectively. The composites modified by the addition of $\mathrm{a} \mathrm{TiB}_{2}$ phase were characterized by intermediate values of the friction coefficient. Average values of the friction coefficient for $70 \mathrm{SiC}$ (sub-micro)/30 $\mathrm{Si}_{3} \mathrm{~N}_{4}$ (sub-micro, Starck) +8 vol. $\% \mathrm{TiB}_{2}$ (micro) and $70 \mathrm{SiC}$ (submicro)/30 $\mathrm{Si}_{3} \mathrm{~N}_{4}$ (sub-micro, Starck) +30 vol. $\% \mathrm{TiB}_{2}$ (micro) materials were 0.48 and 0.46 respectively. The composite with the addition of $30 \% \mathrm{cBN}$ was characterized by the lowest average coefficient of friction, at only 0.36. High coefficients of friction generate thermal stress, which is detrimental to the wear behavior of materials. Hard ceramic bodies possessing high fracture toughness and low coefficients of friction - used in mechanical 
systems that involve high loads, velocities and temperatures, will reduce costs and be less harmful to the environment.

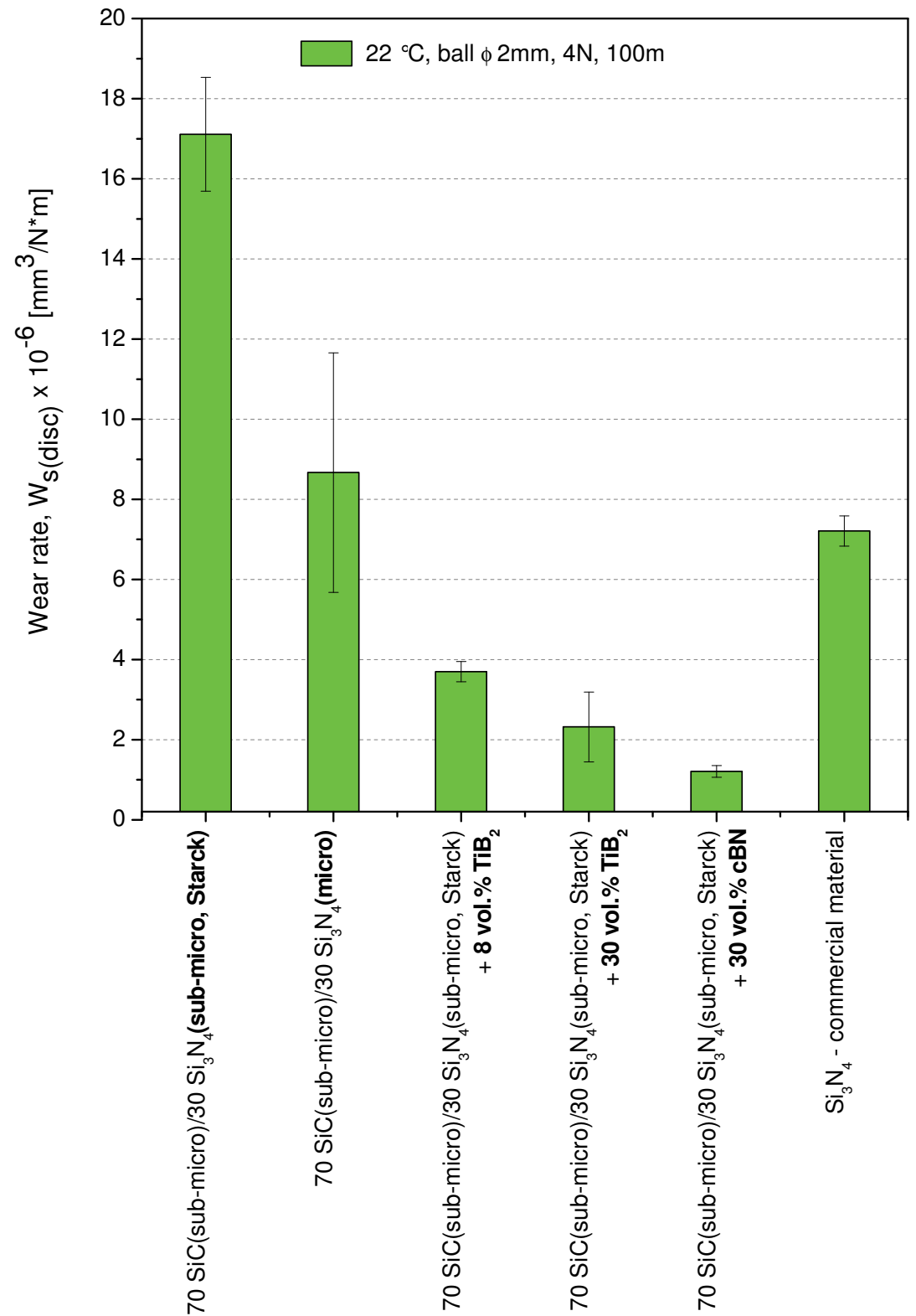

Fig. 15. Wear rate of selected $70 \mathrm{SiC} / 30 \mathrm{Si}_{3} \mathrm{~N}_{4}-$ vol.\% composites with and without the addition of $\mathrm{TiB}_{2}$ and $\mathrm{cBN}$ 
Specific wear rates of investigated materials, in most cases, show a similar trend to the trends exhibited by their coefficients of friction. Only $70 \mathrm{SiC} / 30 \mathrm{Si}_{3} \mathrm{~N}_{4}$ composites without addition of third phase and commercial material show some deviations from this trend. $70 \mathrm{SiC}$ (sub-micro)/30 $\mathrm{Si}_{3} \mathrm{~N}_{4}$ (sub-micro, Starck) composite is the least wear resistant. Their specific wear rate reached value of $17.1 \times 10^{-6} \mathrm{~mm}^{3} / \mathrm{N} \cdot \mathrm{m}$. Subsequently $70 \mathrm{SiC}$ (submicro)/30 $\mathrm{Si}_{3} \mathrm{~N}_{4}$ (micro) and commercial material are classified. Their specific wear rates are $8.7 \times 10^{-6}$ and $7.2 \times 10^{-6} \mathrm{~mm}^{3} / \mathrm{N} \cdot \mathrm{m}$ respectively. Significantly better are composites modified by addition of $\mathrm{TiB}_{2}$ particels. The specific wear rate of $70 \mathrm{SiC}$ (sub-micro)/30 $\mathrm{Si}_{3} \mathrm{~N}_{4}$ (submicro, Starck) +8 vol. $\% \mathrm{TiB}_{2}$ (micro) and $70 \mathrm{SiC}$ (sub-micro) $/ 30 \mathrm{Si}_{3} \mathrm{~N}_{4}$ (sub-micro, Starck)+ 30 vol. \% $\mathrm{TiB}_{2}$ (micro) samples equal $3.7 \times 10^{-6}$ and $2.3 \times 10^{-6} \mathrm{~mm}^{3} / \mathrm{N} \cdot \mathrm{m}$ respectively. The highest wear resistant is exhibited by $70 \mathrm{SiC}$ (sub-micro)/30 $\mathrm{Si}_{3} \mathrm{~N}_{4}$ (sub-micro, Starck) + 30 vol.\% $\mathrm{cBN}\left(\right.$ micro) composite with its specific wear rate value equals only $1.2 \times 10^{-6} \mathrm{~mm}^{3} / \mathrm{N} \cdot \mathrm{m}$.

\section{Conclusions}

The performed research proves that the HPHT sintering is a method of the future for compacting $\mathrm{SiC} / \mathrm{Si}_{3} \mathrm{~N}_{4}$ nanopowders, due to the short time of the process amounting to 40 seconds that permits the grain growth limitations. The obtained compacts were characterized by the crystallites sizes of 4 to $143 \mathrm{~nm}$, depending on the sintering parameters. $\mathrm{SiC}$ and $\mathrm{SiC} / \mathrm{Si}_{3} \mathrm{~N}_{4}$ samples sintered from nanopowders are characterized by the presence of cracks. Cracking of such ceramics occurs as a result of residual micro- and macro-stresses in their structure which overcome the strength of the produced material. The fine powder is characterized by a very large specific surface and high gas content in the sample due to the absorption process of the material particles. During heating, as a result of the increase in temperature, the volume of gases increases, which causes cracking or even permanent fragmentation of the sample. The research regarding the mechanical properties of $\mathrm{SiC} / \mathrm{Si}_{3} \mathrm{~N}_{4}$ composites indicates that materials obtained from submicron powders display the best properties. Density and Young's modulus of the best $70 \mathrm{SiC} / 30 \mathrm{Si}_{3} \mathrm{~N}_{4}$ - vol.\% compacts, sintered at $1880{ }^{\circ} \mathrm{C}$, were $3.18 \mathrm{~g} / \mathrm{cm}^{3}$ (over $99 \%$ the theoretical values) and $377 \mathrm{GPa}$ respectively. This material is also characterized by the highest hardness (HV1 3000) and relatively good fracture toughness $\left(4.9 \mathrm{MPa} \cdot \mathrm{m}^{1 / 2}\right)$. The same material sintered at a lower temperature $\left(1690^{\circ} \mathrm{C}\right)$ has slightly lower values of density $\left(3.14 \mathrm{~g} / \mathrm{cm}^{3}\right)$, Young's modulus (363 GPa) and hardness (HV1 2626) but higher fracture toughness (5.6 MPa.m²). HPHT sintered sub-micro-70 SiC/ $30 \mathrm{Si}_{3} \mathrm{~N}_{4}$ - vol.\% composites have a better combination of mechanical properties than comparable commercial materials.

The research concerning mmodification of sub-micro-70 SiC/30 $\mathrm{Si}_{3} \mathrm{~N}_{4}-$ vol.\% composites proves that the addition of the third phase in the form of $\mathrm{TiB}_{2}$ or $\mathrm{CBN}$ particles contribute to their further improvement. Composites modified by the addition of 30vol.\% cBN micropowder are characterized by the best combination of Young's modulus, hardness, fracture toughness, coefficient of friction and the specific wear rate. Such properties predispose $70 \mathrm{SiC} / 30 \mathrm{Si}_{3} \mathrm{~N}_{4}+30 \mathrm{vol}$. $\% \mathrm{cBN}$ composites to various advanced engineering applications including their use for wear parts and cutting tools.

\section{Acknowledgments}

This study was carried out within the framework of the project funded by the Polish Ministry of Science and Higher Education (Project number: DPN/N111/BIALORUS/2009). 
The author would like to thank Prof. M. Bućko from AGH University of Science and Technology in Krakow for XRD analysis. The author would also like to thank his colleagues from The Institute of Advanced Manufacturing Technology in Krakow for Vickers's indentation tests and for SEM studies. Finally, the author would like to thank his supervisor Prof. L. Jaworska for her optimism and valuable advice throughout this research.

\section{References}

Ando, K.; Houjyou, K.; Chu, M.C.; Takeshita, S.; Takahashi, K.; Sakamoto, S. \& Sato, S. (August 2002). Crack-healing behavior of $\mathrm{Si}_{3} \mathrm{~N}_{4} / \mathrm{SiC}$ ceramics under stress and fatigue strength at the temperature of healing $\left(1000{ }^{\circ} \mathrm{C}\right)$. Journal of the European Ceramic Society, Vol. 22, No. 8, pp. 1339 - 1346, ISSN 0955-2219

Awaji, H.; Choi, S. \& Yagi, E. (July 2002). Mechanisms of toughening and strengthening in ceramic-based nanocomposites. Mechanics of Materials, Vol. 34, No. 7, pp. 411 - 422, ISSN 0167-6636

Bridgman, P.W. (1964). Collected Experimental Papers, Harvard University Press, ISBN 0674137507, Cambridge, Massachusetts, USA

Derby, B. (October 1998). Ceramic nanocomposites: mechanical properties. Current Opinion in Solid State and Materials Science, Vol. 3, No. 5, pp. 490-495, ISSN 1359-0286

Eblagon, F.; Ehrle, B.; Graule, T. \& Kuebler, J. ( 2007). Development of silicon nitride/silicon carbide composites for wood-cutting tools. Journal of the European Ceramic Society, Vol. 27, No. 1, pp. 419 - 428, ISSN 0955-2219

Eremets, M.I. (1996). High pressure Experimental Methods, Oxford University Press, ISBN 0-19856269-1, New York, USA

Filonenko, V.P. \& Zibrov, I.P. (September 2001). High-Pressure Phase Transitions of $\mathrm{M}_{2} \mathrm{O}_{5}(\mathrm{M}$ $=\mathrm{V}, \mathrm{Nb}, \mathrm{Ta}$ ) and Thermal Stability of New Polymorphs. Inorganic Materials, Vol. 37, No. 9, pp. 953-959, ISSN 0020-1685

Gahr, K.Z.; Blattner, R.; Hwang, D. \& Pöhlmann, K. (October 2001). Micro- and macrotribological properties of SiC ceramics in sliding contact. Wear, Vol. 250, No. 1-12, pp. 299 - 310, ISSN 0043-1648

Guicciardi, S.; Sciti, D.; Melandri, C. \& Pezzotti, G. (February 2007). Dry sliding wear behavior of nano-sized $\mathrm{SiC}$ pins against $\mathrm{SiC}$ and $\mathrm{Si}_{3} \mathrm{~N}_{4}$ discs. Wear, Vol. 262, No. 5-6, pp. 529 - 535, ISSN 0043-1648

Hall, H.T. (February 1960). Ultra-High-Pressure, High-Temperature Apparatus: the "Belt". Review of Scientific Instruments , Vol. 31, No. 2, pp. 125-131, ISSN 0034-6748

Hirano, T. \& Niihara, K. (March 1995). Microstructure and mechanical properties of $\mathrm{Si}_{3} \mathrm{~N}_{4} / \mathrm{SiC}$ composites. Materials Letters, Vol. 22, No. 5-6, pp. 249 - 254, ISSN 0167577X

Khvostantsev, L.G.; Slesarev, V.N. \& Brazhkin, V.V. ( 2004). Toroid type high-pressure device: history and prospects. High Pressure Research, Vol. 24, No. 3, pp. 371-383, ISSN

Kim, Y.; Lee, Y. \& Mitomo, M. (August 2006). Sinterability of Nano-Sized Silicon Carbide Powders. Journal of the Ceramic Society of Japan, Vol. 114, No. 1332, pp. 681-685, ISSN 0914-5400

Kinoshita, T.; Munekawa, S. \& Tanaka, S.I. (February 1997). Effect of grain boundary segregation on high-temperature strength of hot-pressed silicon carbide. Acta Materialia, Vol. 45, No. 2, pp. 801 - 809, ISSN 1359-6454 
Lee, S.M.; Kim, T.W.; Lim, H.J.; Kim, C.; Kim, Y.W. \& Lee, K.S. (May 2007). Mechanical Properties and Contact Damages of Nanostructured Silicon Carbide Ceramics. Journal of the Ceramic Society of Japan, Vol. 115, No. 1341, pp. 304-309, ISSN 09145400

Lojanová, S.; Tatarko, P.; Chlup, Z.; Hnatko, M.; Dusza, J.; Lencés, Z. \& Sajgalík, P. (July 2010). Rare-earth element doped $\mathrm{Si}_{3} \mathrm{~N}_{4} / \mathrm{SiC}$ micro/nano-composites--RT and HT mechanical properties. Journal of the European Ceramic Society, Vol. 30, No. 9, pp. 1931 - 1944, ISSN 0955-2219

Magnani, G.; Minoccari, G. \& Pilotti, L. (June 2000). Flexural strength and toughness of liquid phase sintered silicon carbide. Ceramics International, Vol. 26, No. 5, pp. 495 500, ISSN 0272-8842

Manghnani, M.; Ming, L. \& Jamieson, J. (November 1980). Prospects of using synchrotron radiation facilities with diamond-anvil cells: High-pressure research applications in geophysics. Nuclear Instruments and Methods, Vol. 177, No. 1, pp. 219 - 226, ISSN 0029-554X

Murthy, V.S.R.; Kobayashi, H.; Tamari, N.; Tsurekawa, S.; Watanabe, T. \& Kato, K. (July 2004). Effect of doping elements on the friction and wear properties of $\mathrm{SiC}$ in unlubricated sliding condition. Wear, Vol. 257, No. 1-2, pp. 89 - 96, ISSN 00431648

Niihara, K.; Kusunose, T.; Kohsaka, S.; Sekino, T. \& Choa, Y.H. ( 1999). Multi-Functional Ceramic Composites trough Nanocomposite Technology. Key Engineering Materials , Vol. 161-163, No. , pp. 527-534, ISSN 1013-9826

Piermarini, G.J. (2008). Diamond Anvil Cell Techniques, In: Static Compression of Energetic Materials, S.M. Peiris \& G.J. Piermarini, (Eds.), 1-74, Springer, ISBN 978-3-540-681465, Berlin Heidelberg, Germany

Prikhna, A. (February 2008). High-pressure apparatuses in production of synthetic diamonds (Review). Journal of Superhard Materials, Vol. 30, No. 1, pp. 1-15, ISSN 1063-4576

Richerson, D.W. (2004). Advanced ceramic materials, In: Handbook of advanced materials, J.K. Wessel, (Ed.), 65-88, John Wiley \& Sons, Inc., ISBN 0-471-45475-3, Hoboken, New Jersey, USA

Sajgalík, P.; Hnatko, M.; Lofaj, F.; Hvizdos, P.; Dusza, J.; Warbichler, P.; Hofer, F.; Riedel, R.; Lecomte, E. \& Hoffmann, M.J. (April 2000). SiC/ $\mathrm{Si}_{3} \mathrm{~N}_{4}$ nano/micro-composite -processing, RT and HT mechanical properties. Journal of the European Ceramic Society, Vol. 20, No. 4, pp. 453 - 462, ISSN 0955-2219

Suyama, S.; Kameda, T. \& Itoh, Y. (March-July 2003). Development of high-strength reaction-sintered silicon carbide. Diamond and Related Materials, Vol. 12, No. 3-7, pp. 1201 - 1204, ISSN 0925-9635

Takahashi, K.; Jung, Y.; Nagoshi, Y. \& Ando, K. (June 2010). Crack-healing behavior of $\mathrm{Si}_{3} \mathrm{~N}_{4} / \mathrm{SiC}$ composite under stress and low oxygen pressure. Materials Science and Engineering: A, Vol. 527, No. 15, pp. 3343 - 3348, ISSN 0921-5093

Tanaka, H.; Hirosaki, N. \& Nishimura, T. (December 2003). Sintering of Silicon Carbide Powder Containing Metal Boride. Journal of the Ceramic Society of Japan, Vol. 111, No. 1300, pp. 878-882, ISSN 0914-5400

$\mathrm{Xu}, \mathrm{C}$. (2005). Effects of particle size and matrix grain size and volume fraction of particles on the toughening of ceramic composite by thermal residual stress. Ceramics International, Vol. 31, No. 4, pp. 537 - 542, ISSN 0272-8842 
Yamada, K. \& Kamiya, N. (March 1999). High temperature mechanical properties of $\mathrm{Si}_{3} \mathrm{~N}_{4}{ }^{-}$ MoSi2 and $\mathrm{Si}_{3} \mathrm{~N}_{4}-\mathrm{SiC}$ composites with network structures of second phases. Materials Science and Engineering A, Vol. 261, No. 1-2, pp. 270 - 277, ISSN 0921-5093

Yeomans, J. (2008). Ductile particle ceramic matrix composites--Scientific curiosities or engineering materials?. Journal of the European Ceramic Society, Vol. 28, No. 7, pp. 1543-1550, ISSN 0955-2219 


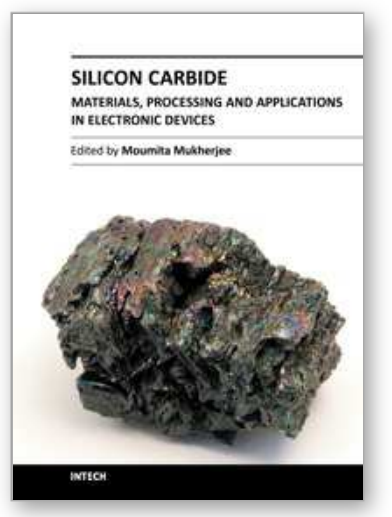

\author{
Silicon Carbide - Materials, Processing and Applications in \\ Electronic Devices \\ Edited by Dr. Moumita Mukherjee
}

ISBN 978-953-307-968-4

Hard cover, 546 pages

Publisher InTech

Published online 10, October, 2011

Published in print edition October, 2011

Silicon Carbide $(\mathrm{SiC})$ and its polytypes, used primarily for grinding and high temperature ceramics, have been a part of human civilization for a long time. The inherent ability of SiC devices to operate with higher efficiency and lower environmental footprint than silicon-based devices at high temperatures and under high voltages pushes SiC on the verge of becoming the material of choice for high power electronics and optoelectronics. What is more important, $\mathrm{SiC}$ is emerging to become a template for graphene fabrication, and a material for the next generation of sub-32nm semiconductor devices. It is thus increasingly clear that $\mathrm{SiC}$ electronic systems will dominate the new energy and transport technologies of the 21st century. In 21 chapters of the book, special emphasis has been placed on the â€œmaterialsâ€ aspects and developments thereof. To that end, about $70 \%$ of the book addresses the theory, crystal growth, defects, surface and interface properties, characterization, and processing issues pertaining to $\mathrm{SiC}$. The remaining $30 \%$ of the book covers the electronic device aspects of this material. Overall, this book will be valuable as a reference for $\mathrm{SiC}$ researchers for a few years to come. This book prestigiously covers our current understanding of $\mathrm{SiC}$ as a semiconductor material in electronics. The primary target for the book includes students, researchers, material and chemical engineers, semiconductor manufacturers and professionals who are interested in silicon carbide and its continuing progression.

\title{
How to reference
}

In order to correctly reference this scholarly work, feel free to copy and paste the following:

Piotr Klimczyk (2011). SiC-Based Composites Sintered with High Pressure Method, Silicon Carbide - Materials, Processing and Applications in Electronic Devices, Dr. Moumita Mukherjee (Ed.), ISBN: 978-953-307-968-4, InTech, Available from: http://www.intechopen.com/books/silicon-carbide-materials-processing-andapplications-in-electronic-devices/sic-based-composites-sintered-with-high-pressure-method

\section{INTECH}

open science | open minds

\section{InTech Europe}

University Campus STeP Ri

Slavka Krautzeka 83/A

51000 Rijeka, Croatia

Phone: +385 (51) 770447

Fax: +385 (51) 686166

\section{InTech China}

Unit 405, Office Block, Hotel Equatorial Shanghai

No.65, Yan An Road (West), Shanghai, 200040, China 中国上海市延安西路65号上海国际贵都大饭店办公楼 405 单元

Phone: +86-21-62489820

Fax: +86-21-62489821 
www.intechopen.com 
(C) 2011 The Author(s). Licensee IntechOpen. This is an open access article distributed under the terms of the Creative Commons Attribution 3.0 License, which permits unrestricted use, distribution, and reproduction in any medium, provided the original work is properly cited. 